University of Nebraska - Lincoln

DigitalCommons@University of Nebraska - Lincoln

\title{
Impact of highly basic solutions on sorption of Cs+ to subsurface sediments from the Hanford site, USA
}

\author{
C.C. Ainsworth \\ Pacific Northwest National Laboratory, calvin.ainsworth@pnl.gov \\ John M. Zachara \\ Pacific Northwest National Laboratory, john.zachara@pnl.gov \\ K. Wagnon \\ Pacific Northwest National Laboratory \\ S. McKinley \\ Pacific Northwest National Laboratory \\ Chongxuan Liu \\ Pacific Northwest National Laboratory, chongxuan.liu@pnl.gov \\ See next page for additional authors
}

Follow this and additional works at: https://digitalcommons.unl.edu/usdoepub

Part of the Bioresource and Agricultural Engineering Commons

Ainsworth, C.C.; Zachara, John M.; Wagnon, K.; McKinley, S.; Liu, Chongxuan; Smith, Steven; Schaef, H.T.; and Gassman, Paul, "Impact of highly basic solutions on sorption of $\mathrm{Cs}+$ to subsurface sediments from the Hanford site, USA" (2005). US Department of Energy Publications. 258.

https://digitalcommons.unl.edu/usdoepub/258

This Article is brought to you for free and open access by the U.S. Department of Energy at DigitalCommons@University of Nebraska - Lincoln. It has been accepted for inclusion in US Department of Energy Publications by an authorized administrator of DigitalCommons@University of Nebraska - Lincoln. 


\section{Authors}

C.C. Ainsworth, John M. Zachara, K. Wagnon, S. McKinley, Chongxuan Liu, Steven Smith, H.T. Schaef, and Paul Gassman 
doi:10.1016/j.gca.2005.06.007

\title{
Impact of highly basic solutions on sorption of $\mathrm{Cs}^{+}$to subsurface sediments from the Hanford site, USA
}

\author{
C. C. Ainsworth, * J. M. Zachara, K. Wagnon, S. McKinley, C. Liu, S. C. Smith, H. T. Schaef, and P. L. Gassman \\ Pacific Northwest National Laboratory, MSIN P7-54, P.O. Box 999, Richland, WA USA
}

(Received June 18, 2004; accepted in revised form June 14, 2005)

\begin{abstract}
The effect of caustic $\mathrm{NaNO}_{3}$ solutions on the sorption of ${ }^{137} \mathrm{Cs}$ to a Hanford site micaceous subsurface sediment was investigated as a function of base exposure time (up to $168 \mathrm{~d}$ ), temperature $\left(10^{\circ} \mathrm{C}\right.$ or $50^{\circ} \mathrm{C}$ ), and $\mathrm{NaOH}$ concentration $(0.1 \mathrm{~mol} / \mathrm{L}$ to $3 \mathrm{~mol} / \mathrm{L})$. At $10^{\circ} \mathrm{C}$ and $0.1 \mathrm{M} \mathrm{NaOH}$, the slow evolution of $[\mathrm{Al}]_{\mathrm{aq}}$ was in stark contrast to the rapid increase and subsequent loss of $[\mathrm{Al}]_{\mathrm{aq}}$ observed at $50^{\circ} \mathrm{C}$ (regardless of base concentration). Exposure to $0.1 \mathrm{M} \mathrm{NaOH}$ at $10^{\circ} \mathrm{C}$ for up to $168 \mathrm{~d}$ exhibited little if any measurable effect on sediment mineralogy, $\mathrm{Cs}^{+}$sorption, or $\mathrm{Cs}^{+}$selectivity; sorption was well described with a two-site ion exchange model modified to include enthalpy effects. At $50^{\circ} \mathrm{C}$, dissolution of phyllosilicate minerals increased with $[\mathrm{OH}]$. A zeolite (tetranatrolite; $\mathrm{Na}_{2} \mathrm{Al}_{2} \mathrm{Si}_{3} \mathrm{O}_{10} \cdot 2 \mathrm{H}_{2} \mathrm{O}$ ) precipitated in $0.1 \mathrm{M} \mathrm{NaOH}$ after about 7 days, while an unnamed mineral phase $\left(\mathrm{Na}_{14} \mathrm{Al}_{12} \mathrm{Si}_{13} \mathrm{O}_{51} \cdot 6 \mathrm{H}_{2} \mathrm{O}\right)$ precipitated after 4 and 2 days of exposure to $1 \mathrm{M}$ and $3 \mathrm{M} \mathrm{NaOH}$ solutions, respectively. Short-term $(16 \mathrm{~h}) \mathrm{Cs}^{+}$sorption isotherms $\left(10^{-9}-10^{-2} \mathrm{~mol} / \mathrm{L}\right)$ were measured on sediment after exposure to $0.1 \mathrm{M} \mathrm{NaOH}$ for 56,112 , and 168 days at $50^{\circ} \mathrm{C}$. There was a trend toward slightly lower conditional equilibrium exchange constants $\left(\Delta \log { }_{N a}^{C s} K_{c} \sim 0.25\right)$ over the entire range of surface coverage, and a slight loss of high affinity sites (15\%) after 168 days of pretreatment with $0.1 \mathrm{M}$ base solution. $\mathrm{Cs}^{+}$sorption to sediment over longer times was also measured at $50^{\circ} \mathrm{C}$ in the presence of $\mathrm{NaOH}(0.1 \mathrm{M}, 1 \mathrm{M}$, and $3 \mathrm{M} \mathrm{NaOH})$ at $\mathrm{Cs}^{+}$concentrations selected to probe a range of adsorption densities. Model simulations of $\mathrm{Cs}^{+}$sorption to the sediment in the presence of $0.1 \mathrm{M} \mathrm{NaOH}$ for 112 days slightly under-predicted sorption at the lower $\mathrm{Cs}^{+}$adsorption densities. At the higher adsorption densities, model simulations under-predicted sorption by $57 \%$. This under-prediction was surmised to be the result of tetranatrolite precipitation, and subsequent slow $\mathrm{Na} \rightarrow \mathrm{Cs}$ exchange. At higher $\mathrm{OH}$ concentrations, $\mathrm{Cs}^{+}$ sorption in the presence of base for 112 days was unexpectedly equal to, or greater than that expected for pristine sediment. The precipitation of secondary phases, coupled with the fairly unique mica distribution and quantity across all size-fractions in the Hanford sediment, appears to mitigate the impact of base dissolution on $\mathrm{Cs}^{+}$sorption. Copyright (C) 2005 Elsevier Ltd
\end{abstract}

\section{INTRODUCTION}

The extraction of $\mathrm{Pu}$ and other strategic materials from irradiated uranium fuels generates large volumes of high-level nuclear waste (HLW). A major component of the Pu reprocessing waste is ${ }^{137} \mathrm{Cs}$, a high yield fission product $\left(\mathrm{t}_{1 / 2}=37.5 \mathrm{yr}\right)$, that is of environmental concern because of its high-energy gamma emission. In the United States, HLW is stored at DOE facilities including Hanford, Idaho National Engineering Laboratory, and Savannah River in massive underground tanks. At the Hanford site, large concentrations of ${ }^{137} \mathrm{Cs}$-containing HLW has been released to the vadose zone and discharged to the soil surface. ${ }^{137} \mathrm{Cs}$ migration through the micaceous Hanford sediments, under normal conditions is limited. However, concerns exist that the highly alkaline and saline nature of these wastes might decrease sediment sorptivity and expedite ${ }^{137} \mathrm{Cs}$ migration.

Previously, Zachara et al. (2002) demonstrated that ion exchange controlled $\mathrm{Cs}^{+}$sorption to the Hanford sediment, whose layer aluminosilicate minerals selectively sorbed $\mathrm{Cs}^{+}$ over other monovalent cations. Similar $\mathrm{Cs}^{+}$behavior has been observed in soils, and sediments by others (Francis and Brinkley, 1976; Evans et al., 1983; Maes and Cremers, 1986; Cre-

* Author to whom correspondence should be addressed (calvin. ainsworth@pnl.gov). mers et al., 1988; Grütter et al., 1990; Wauters et al., 1996a, 1996b; Chitra et al., 1999). Hanford sediment $\mathrm{Cs}^{+}$exchange was well described by a two site ion exchange model (Zachara et al., 2002), which incorporated the sites existing along the frayed edges of micaeous minerals [high energy, frayed edge sites (FES)] and the basal plane of expandable layer silicates such as smectite and vermiculite (low-energy sites).

The clay-sized fraction of the Hanford sediment (smectite, chlorite, kaolinite, and mica) is small by mass ( $2-4 \%$ by wt), but accounts for a substantial portion of the low-affinity (basal plane) exchange sites that define the cation exchange capacity (CEC). This size fraction should be most susceptible to base attack because of its small grain-size. Equally, FES sites associated with micas edges may be altered by acid attack (Turpault and Trotignon, 1994; Kaviratna and Pinnavaia, 1995; Kalinowski and Schweda, 1996) and base attack (Samson et al., 2005), which arises because edge structures are more dissolution reactive than the basal plane. The large free hydroxide concentration of some leaked HLW fluids $(\sim 5 \mathrm{~mol} / \mathrm{L})$ could attack mineral edges and increase the rate of mica interlayer expansion, basal plane exposure, and $\mathrm{K}^{+}$release (Samson et al., 2005). These and other phenomena may affect the concentrations and site distributions of exchange sites, and their ion exchange selectivity for $\mathrm{Cs}^{+}$.

Under alkaline $\mathrm{pH}$ conditions, aluminosilicate precipitates, and particularly zeolites, have been observed from dissolution 
of kaolinite (Bauer et al., 1998), volcanic glass (Hawkins, 1981), Opalinus shale (Chermak, 1992, 1993), and fly ash (Lin and Hsi, 1995; Amrhein et al., 1996; Ma et al., 1998). In systems meant to simulate the high $\mathrm{pH}$, saline, and aluminate concentrations of some Hanford HLW fluids cancrinite was observed to precipitate from suspensions of quartz (Bickmore et al., 2001), and chabazite and the zeolite-like feldpathoids sodalite and cancrinite precipitated from kaolinite suspensions that sorbed $\mathrm{Cs}^{+}$from the HLW fluids (Chorover et al., 2003). Exposure of Hanford sediment to simulated alkaline HLW fluid at elevated temperatures $\left(60-200^{\circ} \mathrm{C}\right)$ resulted in the precipitation of cancrinite and analcime (an aluminosilicate zeolite), both of which sorbed/incorporated $\mathrm{Cs}^{+}$(Nyman et al., 2000). Similarly, cancrinite and sodalite precipitated from Hanford sediment when reacted with simulated alkaline HLW fluids at $50^{\circ} \mathrm{C}$ (Qafoku et al., 2003a, 2003b).

Sediment exposure to high $\mathrm{pH}$ solutions results in mineral dissolution, transformation, and secondary mineral precipitation. The impact of these reactions on $\mathrm{Cs}^{+}$sorption, however, is less certain. Here we investigate the effect of temperature, and base catalyzed dissolution on $\mathrm{Cs}^{+}$sorption behavior to a subsurface sediment typical of material beneath the HLW tanks at the Hanford site. The micaceous sediments used in these studies were those utilized by Zachara et al. (2002) to investigate the effect of electrolyte composition and concentration on $\mathrm{Cs}^{+}$adsorption. Sediments were reacted with $0.1 \mathrm{M} \mathrm{NaOH}$ at $10^{\circ} \mathrm{C}$ and $50^{\circ} \mathrm{C}$ for 168 days. At various stages, sediment samples were removed and washed with a $\mathrm{NaNO}_{3}$ solution until supernatant $\mathrm{pH}$ was about 8 , and then exposed to a range of $\mathrm{Cs}^{+}$concentrations $\left(10^{-9}-10^{-2} \mathrm{~mol} / \mathrm{L}\right)$ to investigate shortterm $(16 \mathrm{~h}) \mathrm{Cs}^{+}$exchange. The impact of base dissolution on $\mathrm{Na} \rightarrow \mathrm{Cs}^{+}$exchange was investigated through the calculation of conditional exchange constants and comparison to those determined by Zachara et al. (2002). A second set of studies followed the sorption of $\mathrm{Cs}^{+}$to the Hanford sediment in the presence of $0.1 \mathrm{M}, 1 \mathrm{M}$, and $3 \mathrm{M} \mathrm{NaOH}$ over a 112-day period. Three $\mathrm{Cs}^{+}$concentrations were used in these studies to evaluate the evolving effects of base catalyzed dissolution on high, intermediate, and low $\mathrm{Cs}^{+}$adsorption densities. The aqueous chemical evolution of sediment exposed to $0.1 \mathrm{M}, 1 \mathrm{M}$ and $3 \mathrm{M}$ $\mathrm{NaOH}$ was followed with time. Electron microscopy, electron micoprobe, and XRD were used to delineate mineralogic changes to the sediment and a two site ion exchange model incorporating enthalpy effects was used to evaluate the effects of base contact on $\mathrm{Cs}^{+}$adsorption.

\section{EXPERIMENTAL PROCEDURES}

\subsection{Sediment Preparation and Properties}

A homogenized, composite sediment was prepared from core samples taken in the construction of four Resource Conservation Recovery Act (RCRA) monitoring wells surrounding the S-SX tank farm at the U.S. Department of Energy's Hanford site in Washington state. As previously described (Zachara et al., 2002), carbonate materials were removed by treatment with sodium acetate $(\mathrm{NaOAc}$ at $\mathrm{pH} 5)$ and the sediment exchange complex was Na-saturated. After this treatment, the cation exchange capacity (CEC) of the Na-saturated sediment was determined to be $4.26 \times 10^{-5} \pm 0.12 \times 10^{-5} \mathrm{eq} / \mathrm{g}$ (Zachara et al., 2002). The low CEC values reflect the small clay mass $(<2 \%)$ of the sediment. Particle size distribution of the sediment categorized it as sandy silt. Sediment mineralogical analyses of the various particle sizes were performed by X-ray diffraction (XRD) and optical microscopy.
For fractions $>2 \mu \mathrm{m}$, quartz was dominant with lesser amounts of plagioclase, potassium feldspars, and micas. The micas were characterized as muscovite, biotite and vermiculitized biotite. The clay size fraction $(<2 \mu \mathrm{m})$ consisted of smectite, chlorite (clinochlore), and mica (for a more detailed description of mineralogy see Zachara et al., 2002; Serne et al., 2002b).

\subsection{Base Treatment of Sediments}

Batch reactors were used to investigate the impact of $\mathrm{NaOH}$ on the Hanford sediment mineral assemblage and the sediment's affinity for ${ }^{137} \mathrm{Cs}^{+}$. Hydroxyl concentrations were set at about $0.1,1.0$, and $3.0 \mathrm{M}$. At $0.1 \mathrm{M} \mathrm{NaOH}$, studies were performed at $10^{\circ} \mathrm{C}$ and $50^{\circ} \mathrm{C}$ with $1 \mathrm{M}$ $\mathrm{NaNO}_{3}$ as a background electrolyte. All other base concentration studies were conducted at $50^{\circ} \mathrm{C}$ with $1 \mathrm{M} \mathrm{NaNO}_{3}$ electrolyte. Subsurface temperatures beneath the S-SX tank farm at Hanford have remained above $50^{\circ} \mathrm{C}$ for over 20 years due to the thermal load of radioactive decay in the stored HLW. A large solution to solid ratio (40) was used to minimize hydroxyl consumption resulting from sediment dissolution and secondary mineral precipitation. Aqueous solutions were analyzed for $\mathrm{Al}, \mathrm{Si}, \mathrm{Ca}, \mathrm{Mg}, \mathrm{Fe}$, and $\mathrm{K}$ by ICP-MS (PerkinElmer Elan 5000) or ICP-AES (Perkin-Elmer 5000) depending on the dilutions required because of the high salt concentrations. Analytical standards and blanks were produced with the same materials used in preparing the sediment suspension solutions. The analysis of $\mathrm{K}^{+}$in these high sodium systems was difficult due to the need for large dilutions, potassium's fairly high detection limit with ICP-AES, and the potential for polyion interferences (e.g., Na-O) with ICP-MS. These analytical problems probably affected the absolute concentrations of $\mathrm{K}^{+}$but not the trends observed.

\subsubsection{Sediment treated with $0.113 \mathrm{M} \mathrm{NaOH}$}

$\mathrm{NaOAc}$-treated Hanford sediment was contacted with $0.113 \mathrm{M}$ $\mathrm{NaOH} / 1 \mathrm{M} \mathrm{NaNO}_{3}$ for $1 \mathrm{hr}, 4 \mathrm{hr}, 8 \mathrm{hr}, 1 \mathrm{~d}, 3 \mathrm{~d}, 7 \mathrm{~d}, 14 \mathrm{~d}, 28 \mathrm{~d}, 42 \mathrm{~d}$, $56 \mathrm{~d}, 112 \mathrm{~d}$ and $168 \mathrm{~d}$ (for convenience, $0.113 \mathrm{M} \mathrm{NaOH}$ is hereafter referred to as $0.1 \mathrm{M})$. $\mathrm{NaOH}$ solutions and sediment suspensions were synthesized and kept under a $\mathrm{N}_{2(\mathrm{~g})}$ atmosphere throughout the studies to limit $\mathrm{CO}_{2(\mathrm{~g})}$ and $\mathrm{O}_{2(\mathrm{~g})}$ absorption. Suspensions were continuously agitated on an orbital shaker $(30 \mathrm{rpm})$ for the first 3 days, and then vigorously agitated by hand for several minutes twice a day for the remaining days. The $56 \mathrm{~d}, 112 \mathrm{~d}$, and $168 \mathrm{~d}$ samples used $250-\mathrm{mL}$ Teflon bottles and carried six replicates; all other time period samples used Teflon Oak Ridge centrifuge tubes, and carried duplicate samples. Replication number was based on the need for ample sediment to perform specific analyses after each time period (i.e., CEC, Cs adsorption, and where feasible, XRD and SEM.). Identical sample sets were carried out at $50^{\circ} \mathrm{C}$ and $10^{\circ} \mathrm{C}$.

The samples were centrifuged $(5,000 \mathrm{RCF}$ [relative centrifuge force] for $30 \mathrm{~min}$ ) at temperature, placed in a $\mathrm{N}_{2(\mathrm{~g})}$ glove box, and the supernatant decanted for determination of $\mathrm{pH}$, and $\mathrm{Al}, \mathrm{Si}, \mathrm{Fe}, \mathrm{Ca}, \mathrm{Mg}$, and $\mathrm{K}$ for each sampling point. Most of the supernatant was immediately diluted ( 1 to $10 \mathrm{v} / \mathrm{v})$ to prevent precipitation as the samples equilibrated to room temperature. A 3 to $5 \mathrm{~mL}$ sample of the original supernatant was utilized for $\mathrm{pH}$ determination, prior to any significant cooling (or warming) of the sample. After decanting the supernatant, the solids from replicate temperature and time elements were placed in a filter system $(0.2 \mu \mathrm{m}$ filter $)$, and washed with a $\mathrm{pH}$ neutral solution of $0.1 \mathrm{M} \mathrm{NaNO}_{3}$ wash five or six times (total volume $\sim 40 \mathrm{~mL}$ ), followed by $\mathrm{pH} 5.50 .01 \mathrm{M} \mathrm{NaNO}_{3}$ until the filtrate $\mathrm{pH}$ was at or below 8.0 (total volume $\sim 10 \mathrm{~mL}$ ). This was followed by a final wash with $0.01 \mathrm{M}$ $\mathrm{NaNO}_{3}$. All sample manipulation was performed under a $\mathrm{N}_{2(\mathrm{~g})}$ atmosphere. Sediments were air-dried and stored under a $\mathrm{N}_{2(\mathrm{~g})}$ atmosphere at room temperature.

\subsubsection{Sediment treated with $1 \mathrm{M}$ and $3 \mathrm{M} \mathrm{NaOH}$}

$\mathrm{NaOAc}$-treated, Na-saturated Hanford sediment was contacted with $1 \mathrm{M} \mathrm{NaOH} / 1 \mathrm{M} \mathrm{NaNO}$, or $3 \mathrm{M} \mathrm{NaOH} / 1 \mathrm{M} \mathrm{NaNO}_{3}$ solutions at $50^{\circ} \mathrm{C}$ for $1 \mathrm{hr}, 8 \mathrm{hr}, 1 \mathrm{~d}, 7 \mathrm{~d}, 14 \mathrm{~d}, 28 \mathrm{~d}, 56 \mathrm{~d}$, and $112 \mathrm{~d}$. The sediments were treated and sampled as previously described. Only $\mathrm{Al}, \mathrm{Si}$, and $\mathrm{K}$ concentrations were determined for each sampling point because of the 
large dilutions required. The $\mathrm{pH}$ was not determined for these materials. Sediments were air-dried and stored under a $\mathrm{N}_{2(\mathrm{~g})}$ atmosphere.

\subsubsection{Cs exchange isotherms on $0.1 \mathrm{M} \mathrm{NaOH}$ pre-treated sediment}

Cesium exchange isotherms were measured on washed, and $\mathrm{pH}$ adjusted $(\sim 8.0)$, base treated sediments $(56 \mathrm{~d}, 112 \mathrm{~d}$, and $168 \mathrm{~d})$ in 1 $\mathrm{M} \mathrm{NaNO}$ electrolyte (see section 2.2.1). Post-treatment, air-dried sediments were washed three times in $1 \mathrm{M} \mathrm{NaNO}_{3}$ and resuspended prior to addition of $\mathrm{CsNO}_{3}$; the solids concentration was $50 \mathrm{~g} / \mathrm{L}$. Exchange measurements were performed in triplicate at $10^{-1}, 10^{-3}$ $10^{-6}$, and $10^{-9} \mathrm{M} \mathrm{CsNO}_{3}$, and in duplicate at $10^{-2}, 10^{-4}, 10^{-5}$, and $10^{-7} \mathrm{M} \mathrm{CsNO}_{3}$. Radiolabeled ${ }^{137} \mathrm{Cs}$ (as $\mathrm{CsCl}$ in $0.1 \mathrm{M} \mathrm{HCl}$ with a specific activity of $3.7 \times 10^{6} \mathrm{mCi} / \mathrm{mol}$ ) was added to yield 7000 to $20,000 \mathrm{dpm} / \mathrm{mL}{ }^{137} \mathrm{Cs}$. The suspensions were shaken for $16 \mathrm{~h}$ at room temperature $\left(\sim 20^{\circ} \mathrm{C}\right)$ in $50-\mathrm{mL}$ polycarbonate tubes at $80 \mathrm{rpm}$. After equilibration, the aqueous phase was separated from the sediment by centrifugation at $5000 \mathrm{rcf}$ for $30 \mathrm{~min}$. The ${ }^{137} \mathrm{Cs}$ in the aqueous phase was determined by gamma radiation counting using a Wallac gamma counter, model 1480 . The count window was set at 560 to $710 \mathrm{keV}$, yielding a counting efficiency of 0.207 . Counting samples were determined by mass and counted for $24 \mathrm{~h}$ or until about 10,000 total counts were obtained. The exchange procedure in the current study followed precisely the procedure used by Zachara et al. (2002).

\subsubsection{Time-dependent $\mathrm{Cs}$ sorption during $\mathrm{NaOH}$ attack}

Time-dependent ${ }^{137} \mathrm{Cs}$ sorption at $10^{\circ} \mathrm{C}$ and $50^{\circ} \mathrm{C}$ was investigated in $0.1 \mathrm{M} \mathrm{NaOH} / 1 \mathrm{M} \mathrm{NaNO}_{3}$ at three Cs concentrations: $2.1 \times 10^{-9}, 1.3$ $\times 10^{-7}$, and $4.5 \times 10^{-5} \mathrm{M} \mathrm{CsNO}_{3}$. Teflon Oak ridge centrifuge tubes $(35-\mathrm{mL})$ were used as batch reactors. The three $\mathrm{Cs}^{+}$concentrations were selected based on results of Zachara et al. (2002), and were selected to populate various exchange site classes: 1$)$ high affinity (4.26 $\left.\left.\times 10^{-11} \mathrm{~mol} / \mathrm{g}\right), 2\right)$ transition $\left(6.75 \times 10^{-9} \mathrm{~mol} / \mathrm{g}\right)$, and 3) low affinity $\left(4.26 \times 10^{-7} \mathrm{~mol} / \mathrm{g}\right)$. Aqueous ${ }^{137} \mathrm{Cs}$ concentrations were determined in the centrifugates by gamma-radiation counting. At $50^{\circ} \mathrm{C},{ }^{137} \mathrm{Cs}$ was determined after $1 \mathrm{hr}, 4 \mathrm{hr}, 8 \mathrm{hr}, 1 \mathrm{~d}, 3 \mathrm{~d}, 7 \mathrm{~d}, 14 \mathrm{~d}, 28 \mathrm{~d}, 42 \mathrm{~d}, 56 \mathrm{~d}$, and $112 \mathrm{~d}$ of base contact in replicate samples. At $10^{\circ} \mathrm{C},{ }^{137} \mathrm{Cs}$ was determined after $14 \mathrm{~d}, 28 \mathrm{~d}, 56 \mathrm{~d}$, and $112 \mathrm{~d}$ of base contact in replicate samples.

Similar time-variant sorption studies were conducted in $1 \mathrm{M} \mathrm{NaOH} / 1$ $\mathrm{M} \mathrm{NaNO}_{3}$ and $3 \mathrm{M} \mathrm{NaOH} / 1 \mathrm{M} \mathrm{NaNO}_{3}$ at $50^{\circ} \mathrm{C}$. These high base experiments used slightly higher concentrations of $\mathrm{CsNO}_{3}: 6.1 \times 10^{-9}$, $4.0 \times 10^{-7}$, and $1.3 \times 10^{-4} \mathrm{M} \mathrm{CsNO}_{3}$ in $1 \mathrm{M} \mathrm{NaOH}$, and $1.3 \times 10^{-8}$, $8.8 \times 10^{-7}$, and $3.0 \times 10^{-4} \mathrm{M} \mathrm{CsNO}_{3}$ in $3 \mathrm{M} \mathrm{NaOH}$. The different $\mathrm{CsNO}_{3}$ concentrations were used to offset the expected decrease in $\mathrm{Cs}^{+}$ sorption due to higher $\mathrm{Na}^{+}$concentrations. Duplicate samples were sacrificed to determine aqueous ${ }^{137} \mathrm{Cs}$ concentrations (by gamma-radiation counting) at $1 \mathrm{~h}, 8 \mathrm{~h}, 1 \mathrm{~d}, 7 \mathrm{~d}, 14 \mathrm{~d}, 28 \mathrm{~d}, 56 \mathrm{~d}$, and $112 \mathrm{~d}$.

\section{3. $\mathrm{pH} / \mathrm{p}[\mathrm{H}]$ Determinations}

The $\mathrm{pH}$ of the $1 \mathrm{M} \mathrm{NaNO}_{3} / 0.1 \mathrm{M} \mathrm{NaOH}$-sediment suspensions with time was determined using a combination $\mathrm{pH}$ glass electrode (OrionRoss, semi-micro). Immediately after decanting the centrifugate a 3 to 5-mL sample was placed in a glove box under $\mathrm{N}_{2(\mathrm{~g})}$ atmosphere, at which time the $\mathrm{pH}$ was determined (see section 2.2.1). For this study, the ability to discern significant changes in $\mathrm{pH}$ as a function of time was more important than determining the precise $\mathrm{pH}$ value of the sediment suspension. However, because of concern of the possible salt effects (liquid junction potentials) and the high base concentration on $\mathrm{pH}$ measurements using a combination glass electrode, a series of Gran titrations of the $1 \mathrm{M} \mathrm{NaNO}_{3}$ solution was performed (Rai et al., 1995). Solutions of $1 \mathrm{M} \mathrm{NaNO}_{3}$ (25-mL aliquots) were titrated with standardized $0.1 \mathrm{M} \mathrm{NaOH}$, or $0.1 \mathrm{M} \mathrm{HNO}_{3}$ using a modified Gran titration in which the moles of added free acid (or base) were plotted against $\mathrm{H}_{\text {obs }}^{+}$ $(\mathrm{pH})$. This technique has been generally used as a simple method for estimating the hydrogen ion concentration $(\mathrm{p}[\mathrm{H}])$ in concentrated salt solutions (1 to $6 \mathrm{M})$. The logarithm of the slope of the titration curve delineates the correction factor $\mathrm{A}$ in the relationship, $\mathrm{p}[\mathrm{H}]=\mathrm{pH}_{\mathrm{ob}}+\mathrm{A}$ (Rai et al., 1995). In the current study this technique was utilized to determine the behavior of the electrode in $1 \mathrm{M} \mathrm{NaNO}_{3}$ and $0.1 \mathrm{M}$ $\mathrm{NaOH}$, and the stability of the $\mathrm{pH}$ measurement.

\subsection{XRD and SEM Analysis of Treated Sediment}

The $\mathrm{NaOH}$ treated sediments at $50^{\circ} \mathrm{C}$ were separated into two particle sizes for X-ray diffraction (XRD) analyses. The sediments were dry-sieved at $53 \mu \mathrm{m}$ to decrease the likelihood of mineral dissolution during separation. The $<53 \mu \mathrm{m}$ sediment fraction was analyzed as a semi-random powder-mount. Clay fractions $(<2 \mu \mathrm{m})$ were obtained from the $<53 \mu \mathrm{m}$ isolate by centrifugation (Jackson, 1969). However, small quantities of the clay-sized fraction limited the XRD analyses to sediments treated with: 1) $0.1 \mathrm{M} \mathrm{NaOH}$ at 56 and 112 days, 2) $1 \mathrm{M} \mathrm{NaOH}$ for 7, 24, and 33 days, and 3) $3 \mathrm{M} \mathrm{NaOH}$ at 7, 24, and 33 days. The particle size separates were dried as soon as possible after separation. The $<2 \mu \mathrm{m}$ isolates were analyzed as oriented smear mounts.

The samples were analyzed using a Philips X'Pert MPD system employing the PW3050/10 vertical theta-theta goniometer and a PW3373 ceramic X-ray tube with $\mathrm{Cu}$ anode. Standard operating power was $2000 \mathrm{~W}(40 \mathrm{kV}, 50 \mathrm{~mA})$. Samples were examined from 2 to 80 degrees $2 \Theta$. Powder samples were mounted in $12-\mathrm{mm}$ diameter shallow cavities in off-axis single-crystal quartz plates (Gem Dugout, State College, PA.). Mineral identification utilized JADE+, V2.1 (Materials Data Inc., Livermore, CA.). The search-match algorithm used the JCPDS Powder Diffraction File reference database (International Centre for Diffraction Data, Newtown Square, PA.).

Scanning electron photomicrographs were collected using a JEOL $6340 \mathrm{~F}$ scanning electron microscope (SEM), operated at an accelerating potential of $10 \mathrm{KeV}$ and a beam current of $10 \mathrm{nA}$. The granular samples were mounted on conductive tape on aluminum stubs, and sputter coated with carbon to assure electrical conductivity. Qualitative compositional data were collected during imaging using an Oxford Isis energy-dispersive spectrometer (EDS).

\subsection{CEC Determinations}

The CEC of the $0.1 \mathrm{M} \mathrm{NaOH}$-treated sediment (section 2.2.1) was determined at $56 \mathrm{~d}, 112 \mathrm{~d}$, and $168 \mathrm{~d}$ as previously described (Zachara et al., 2002). Briefly, after being air-dried, a prescribed mass of sediment was placed in Oak Ridge centrifuge tubes and washed three times with $0.002 \mathrm{M} \mathrm{NaNO}_{3}$ solution to obtain a low $[\mathrm{Na}]_{\mathrm{aq}}$ in the occluded solution prior to addition of the radiotracer solution. Isotopic exchange with ${ }^{22} \mathrm{Na}$ in $0.002 \mathrm{~mol} / \mathrm{L} \mathrm{NaNO}_{3}$ electrolyte was used to determine the Na-based CEC (Babcock and Schultz, 1970). The aqueous phase activity of ${ }^{22} \mathrm{Na}$ after $16 \mathrm{~h}$ equilibration was determined using a Packard 2550 TR/LL liquid scintillation analyzer and Hionic-Fluor (PerkinElmer). As with ${ }^{137} \mathrm{Cs}$, counting samples were determined by mass and counted for $24 \mathrm{~h}$ or until about 10,000 total counts were obtained.

\section{RESULTS AND DISCUSSION}

In this section, we first address the effect of base on the aqueous phase, and solid phase composition. Of particular importance are i) the relationship between base concentration and onset of precipitation; ii) solid precipitate identification; and iii) changes in CEC, which could have significant affects on $\mathrm{Cs}^{+}$sorption. Next, we show and discuss results relevant to the effect of base on $\mathrm{Cs}^{+}$sorption to i) Hanford sediment that had been reacted with $0.1 \mathrm{M}$ base, washed, $\mathrm{pH}$ adjusted back to near-natural $\mathrm{pH}(\sim 8.0)$, and then reacted with $\mathrm{Cs}^{+}$; and ii) the effect of $0.1 \mathrm{M}, 1 \mathrm{M}$, and $3 \mathrm{M}$ base with time on $\mathrm{Cs}^{+}$sorption when sediment, base, and $\mathrm{Cs}^{+}$are present from $\mathrm{t}=0$. Finally, the $\mathrm{Cs}^{+}$adsorption data are compared to pristine sediment $\mathrm{Cs}^{+}$ sorption data through the use of a two-site ion exchange model (Zachara et al., 2002), and variations between base-reacted and pristine sediment focuses on solid phase changes discussed previously. 


\subsection{Evolution of Aqueous Phase Composition in the Presence of Base}

In order to estimate the changes in $\mathrm{pH}$ in the high salt, high base systems of the current study the technique of Rai et al. (1995) was used to estimate the salt effect on the hydrogen ion concentration $\left(\mathrm{p}[\mathrm{H}]=\mathrm{pH}_{\text {obs. }}+\mathrm{A}\right)$. Titration of $1 \mathrm{M} \mathrm{NaNO}_{3}$ with standardized $\mathrm{NaOH}$ yielded a series of linear relationships that were essentially identical, and a correction factor (A) equal to 0.79 . The linearity of the titration data, and its reproducibility suggested that $\mathrm{pH}$ measurements in the present system would be stable and that significant change in $\mathrm{pH}$ with time could be easily detected. The $\mathrm{p}[\mathrm{H}]$ of the sediment suspension in $0.1 \mathrm{M}$ $\mathrm{NaOH}$ and $1 \mathrm{M} \mathrm{NaNO}_{3}$ was fairly constant over the entire length of the study. The initial $\mathrm{p}[\mathrm{H}]$ determinations (at about $2 \mathrm{~h}$ ) were 13.3 and $13.4(\mathrm{pH} 12.5$ and 12.6$)$ at $50^{\circ} \mathrm{C}$ and $10^{\circ} \mathrm{C}$, respectively. Neither the $\mathrm{p}[\mathrm{H}]$ or $\mathrm{pH}$ exhibited any observable pattern indicative of substantial $\mathrm{OH}$ consumption with time; the maximum $\mathrm{p}[\mathrm{H}]$ or $\mathrm{pH}$ variation over the study period was about 0.2 units.

The release of $\mathrm{Al}$ and $\mathrm{Si}$ showed contrasting trends in the variable concentration $\mathrm{NaOH}$ systems at $50^{\circ} \mathrm{C}$ (Fig. 1a, b). Aluminum rapidly dissolved to a maximum, then sharply decreased with equilibration time. $\mathrm{Si}_{\mathrm{aq}}$ began to plateau before $\mathrm{Al}_{\mathrm{aq}}$ reached its maximum, and then increased slightly (1 M and $3 \mathrm{M} \mathrm{NaOH}$ ) toward the end of the study. The time required to attain the maximum $\mathrm{Al}_{\mathrm{aq}}$ was approximately 42,28 , and 14 days at $0.1 \mathrm{M}, 1 \mathrm{M}$, and $3 \mathrm{M} \mathrm{NaOH}$, respectively. During the initial dissolution phase ( $\leq 7$ days depending on base) the $\mathrm{Si}_{\mathrm{aq}} / \mathrm{Al}_{\mathrm{aq}}$ molar ratio was virtually the same (3.7 to 5; Fig $1 \mathrm{c}$ ). Beyond this initial period, the $\mathrm{Si}_{\mathrm{aq}} / \mathrm{Al}_{\mathrm{aq}}$ ratio began to increase, and the extent of increase was dependent on base concentration. The dramatic drop in $\mathrm{Al}_{\mathrm{aq}}$ and the increase in $\mathrm{Si}_{\mathrm{aq}} / \mathrm{Al}_{\mathrm{aq}}$ ratio signified the precipitation of secondary minerals. The precipitation reactions, however, undoubtedly began before the $\mathrm{Al}_{\mathrm{aq}}$ maximum was attained.

In contrast to the $50^{\circ} \mathrm{C}$ data, the $10^{\circ} \mathrm{C}$ evolution profiles of $\mathrm{Al}_{\mathrm{aq}}$ and $\mathrm{Si}_{\mathrm{aq}}$ increased to poorly defined maxima between 84 and 112 days (Fig. 2a, b). The $\mathrm{Al}_{\mathrm{aq}}$ and $\mathrm{Si}_{\mathrm{aq}}$ maxima were approximately one-half and one-third, respectively, of that observed at $50^{\circ} \mathrm{C}$. The $\mathrm{Si}_{\mathrm{aq}} / \mathrm{Al}_{\mathrm{aq}}$ exhibited a near constant value (10.1-12.4) over 112 days (Fig. 2c). Between 112 and 168 days, $\mathrm{Al}_{\mathrm{aq}}$ and $\mathrm{Si}_{\mathrm{aq}}$ exhibited a slight decrease in concentration, and the $\mathrm{Si}_{\mathrm{aq}} / \mathrm{Al}_{\mathrm{aq}}$ deceased by about a factor of 2 . While the decrease in $\mathrm{Al}_{\mathrm{aq}}$ and $\mathrm{Si}_{\mathrm{aq}}$ (at both temperatures) signaled precipitation of secondary minerals, the difference in $\mathrm{Si}_{\mathrm{aq}} / \mathrm{Al}_{\mathrm{aq}}$ evolution with temperature was completely opposite.

Bauer and Berger (1998), investigated kaolinite dissolution in the presence of $\mathrm{KOH}$ using a batch reactor. They observed an initial pure dissolution phase whose instantaneous Si solubilization rate was inversely dependent on $\mathrm{Al}_{\mathrm{aq}}$. The dissolution phase was followed by a second stage that corresponded to a precipitation phase, whose onset disrupted the Si solubilization rate dependence on $\mathrm{Al}_{\mathrm{aq}}$ and was dependent on temperature and $\left[\mathrm{OH}^{-}\right]$(Bauer and Berger, 1998; Bauer et al., 1998). In the current study, assuming $\left[\mathrm{Al}_{\mathrm{tot}}\right]_{\mathrm{aq}} \approx\left[\mathrm{Al}(\mathrm{OH})_{4}^{-}\right]$, the instantaneous rate of $\mathrm{Si}$ solubilization exhibited an early inverse dependence on the $\left[\mathrm{Al}(\mathrm{OH})_{4}^{-}\right] /\left[\mathrm{OH}^{-}\right](\mathrm{Fig} \mathrm{3a}, \mathrm{b})$. However, as $\left[\mathrm{Al}(\mathrm{OH})_{4}^{-}\right] /\left[\mathrm{OH}^{-}\right]$increased the rate of $\mathrm{Si}$ solubilization became almost constant. The constancy in $\mathrm{Si}$ release rate is
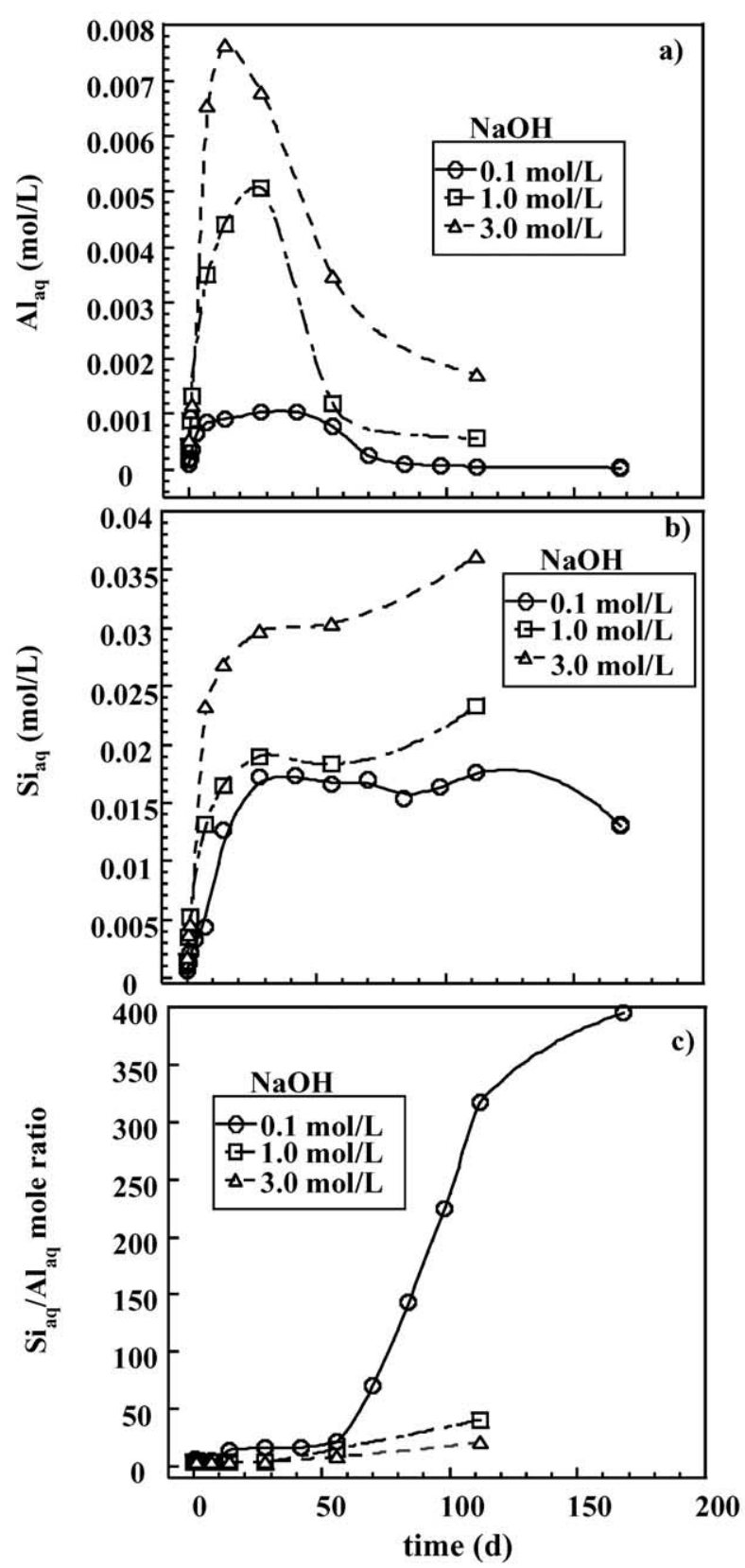

Fig. 1. Aqueous concentration of a) $\mathrm{Al}$, b) $\mathrm{Si}$, and c) $\mathrm{Si} / \mathrm{Al}$ ratio as a function of time for Hanford sediment in contact with $0.1 \mathrm{M}, 1 \mathrm{M}$, and $3 \mathrm{M} \mathrm{NaOH}$ in $1 \mathrm{M} \mathrm{NaNO}_{3}$ at $50^{\circ} \mathrm{C}$.

believed to reflect the onset of precipitation. At $10^{\circ} \mathrm{C}$, this occurs at about $\left[\mathrm{Al}(\mathrm{OH})_{4}^{-}\right] /\left[\mathrm{OH}^{-}\right] \approx 0.0055$ (Fig. 3a), and at approximately $\left[\mathrm{Al}(\mathrm{OH})_{4}^{-}\right] /\left[\mathrm{OH}^{-}\right] \approx 0.002$ at $50^{\circ} \mathrm{C}$ regardless of base concentration (Fig. 3b). These $\left[\mathrm{Al}(\mathrm{OH})_{4}{ }^{-}\right] /\left[\mathrm{OH}^{-}\right]$ratios were attained between 84 and 98 days at $10^{\circ} \mathrm{C}$ in $0.1 \mathrm{M}$ $\mathrm{NaOH}$, and at 7 days, 4 days and 2 days at $50^{\circ} \mathrm{C}$ in $0.1 \mathrm{M}, 1 \mathrm{M}$, and $3 \mathrm{M} \mathrm{NaOH}$, respectively.

\subsection{Base Effects on Sediment Mineralogy}

The sediment developed red coloration with increasing time of base contact, and the intensity of the coloration increased 

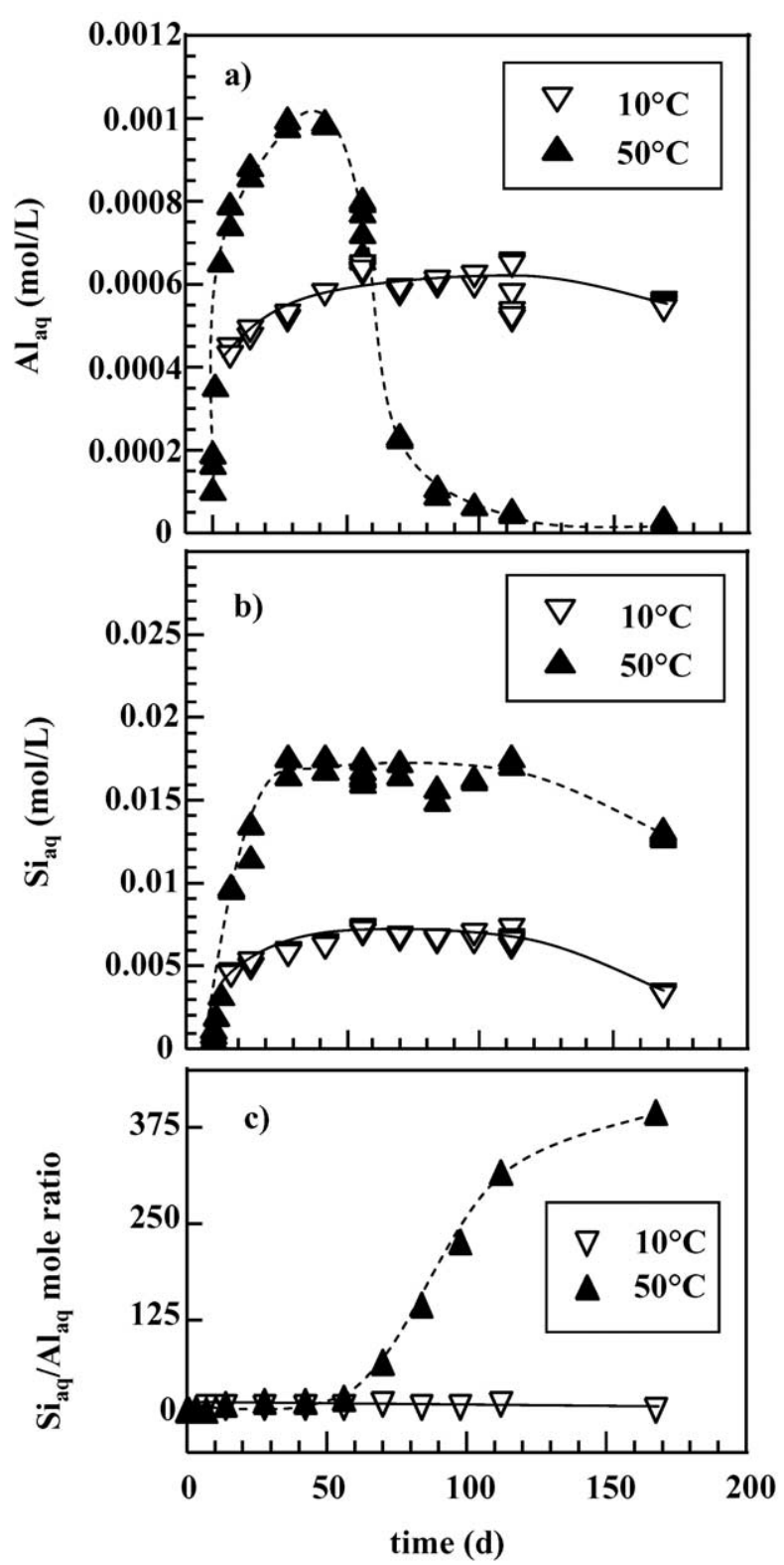

Fig. 2. Aqueous concentration of a) $\mathrm{Al}, \mathrm{b}) \mathrm{Si}$, and c) $\mathrm{Si} / \mathrm{Al}$ ratio as a function of time for the Hanford sediment in contact with $0.1 \mathrm{M} \mathrm{NaOH}$ and $1 \mathrm{M} \mathrm{NaNO}_{3}$ at $10^{\circ} \mathrm{C}$ and $50^{\circ} \mathrm{C}$.

with increasing base concentration at $50^{\circ} \mathrm{C}$. By day 7 , SEM micrographs and EDS analyses of sediment reacted with $1 \mathrm{M}$ and $3 \mathrm{M} \mathrm{NaOH}$ showed the presence of small, iron oxide clusters made up of individual spherical submicron Fe particles (micrographs not shown). Fe oxides of similar morphology were observed after 112 days at the lowest base concentration. $\mathrm{Fe}(\mathrm{III})$ oxide formation resulted from biotite and chlorite dissolution followed by oxidation of solubilized Fe(II). At $10^{\circ} \mathrm{C}$, no visual changes to sediment color were evident, nor were there any significant mineralogic changes that could be discerned by XRD.

After exposure to $0.1 \mathrm{M} \mathrm{NaOH}$ for $56 \mathrm{~d}$ at $50^{\circ} \mathrm{C}$, XRD patterns of Hanford sediment clay-sized fraction $(<2 \mu \mathrm{m})$ showed a secondary precipitate coexisting with residual mica,
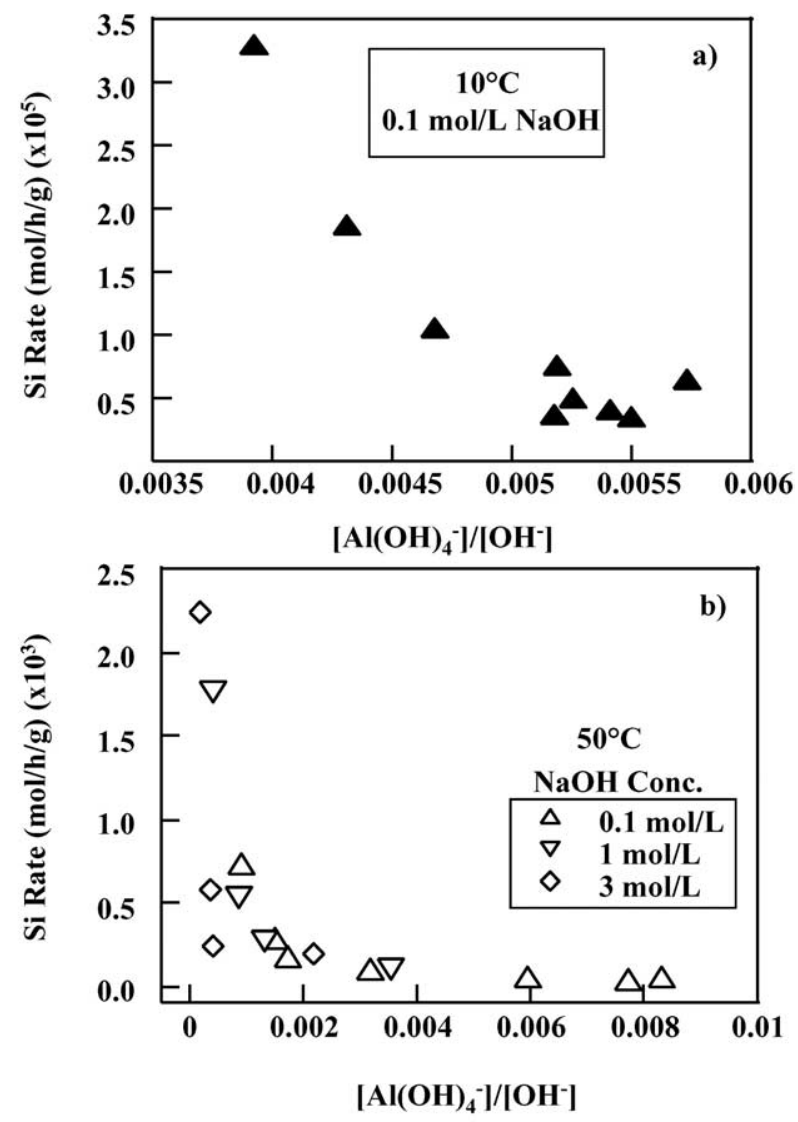

Fig. 3. Instantaneous $\mathrm{Si}$ dissolution rate as a function of the $\mathrm{Al}(\mathrm{OH})_{4}{ }^{-} / \mathrm{OH}^{-}$ratio at a) $10^{\circ} \mathrm{C}$ and b) $50^{\circ} \mathrm{C}$ (only rate data prior to $\mathrm{Al}$ attaining its maximum concentration are presented for $50^{\circ} \mathrm{C}$ ).

chlorite, quartz, and smectite ( $\mathrm{T}$ in Fig. 4). The secondary precipitate was identified as tetranatrolite, a zeolite $\left(\mathrm{Na}_{2} \mathrm{Al}_{2} \mathrm{Si}_{3} \mathrm{O}_{10} \cdot 2 \mathrm{H}_{2} \mathrm{O}\right)$, that has been known to occur in saline or salt affected soils at elevated $\mathrm{pH}$ (Ming and Mumpton, 1989). Comparison of diffraction maxima between the 56-d, 112-d and 168-d samples (data not shown) suggested increasing tetranatrolite, and decreasing phyllosilicates with base contact time. At the higher base treatments $(1 \mathrm{M} \mathrm{NaOH} / 1 \mathrm{M}$

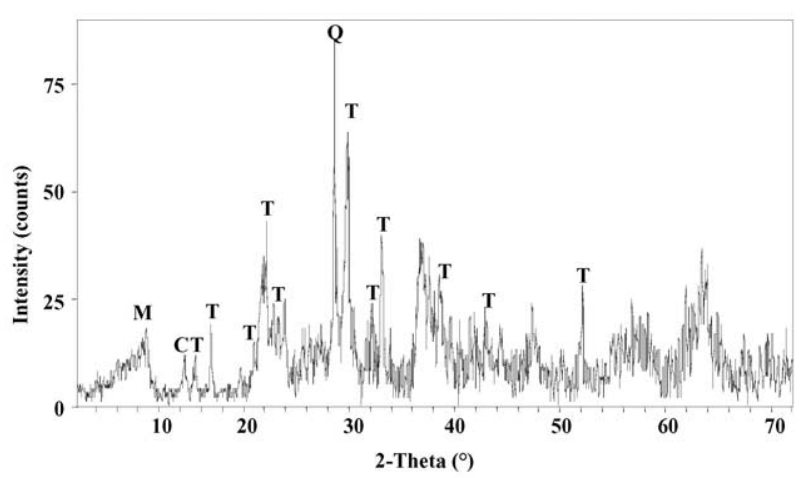

Fig. 4. X-ray diffraction pattern of the $<2 \mu \mathrm{m}$ fraction of Hanford sediment after 112 days in contact with $0.1 \mathrm{M} \mathrm{NaOH}$ in $1 \mathrm{M} \mathrm{NaNO}_{3}$ at $50^{\circ} \mathrm{C}(\mathrm{Q}=$ quartz, $\mathrm{M}=$ mica, $\mathrm{C}=$ chlorite, and $\mathrm{T}=$ tetranatrolite $)$. 


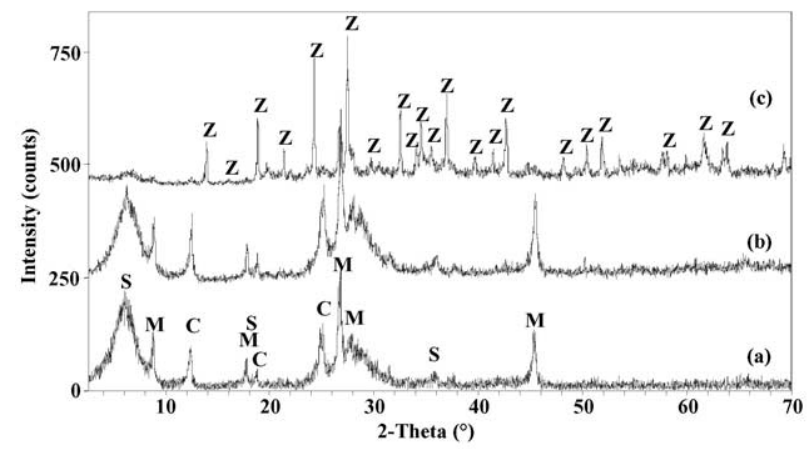

Fig. 5. X-ray diffraction pattern of the $<2 \mu \mathrm{m}$ fraction of Hanford sediment after a) 7 days, b) 24 days, and c) 33 days in contact with 1 $\mathrm{M} \mathrm{NaOH}$ in $1 \mathrm{M} \mathrm{NaNO}_{3}$ at $50^{\circ} \mathrm{C}$ ( $\mathrm{s}=$ smectite, $\mathrm{M}=$ mica, $\mathrm{C}$ $=$ chlorite, $\mathrm{F}=$ feldspar, and $\mathrm{Z}=$ unnamed $\mathrm{Na}_{2} \mathrm{Al}_{2} \mathrm{Si}_{3} \mathrm{O}_{10} \cdot 2 \mathrm{H}_{2} \mathrm{O}$ phase).

$\mathrm{NaNO}_{3}$ and $3 \mathrm{M} \mathrm{NaOH} / 1 \mathrm{M} \mathrm{NaNO}_{3}$ ) the steady disappearance of phyllosilicate diagnostic diffraction peaks was more pronounced. By 33 days the $<2 \mu \mathrm{m}$ fraction smectite, mica, and chlorite diffraction maxima were barely observable, and new set of diffraction maxima (marked by $\mathrm{Z}$ ) associated with an unnamed neoform $\left(\mathrm{Na}_{14} \mathrm{Al}_{12} \mathrm{Si}_{13} \mathrm{O}_{51} \cdot 6 \mathrm{H}_{2} \mathrm{O}\right)$ were revealed (Fig. 5). The secondary phase $\left(\mathrm{Na}_{14} \mathrm{Al}_{12} \mathrm{Si}_{13} \mathrm{O}_{51} \cdot 6 \mathrm{H}_{2} \mathrm{O}\right)$ was identified by the search-match algorithm as JCPDS \#28-1036. A similar sodium aluminum silicate hydrate mineral phase had been observed to precipitate in fly ash treated with $3 \mathrm{M} \mathrm{NaOH}$ at $100^{\circ} \mathrm{C}$ (Amrhein et al., 1996).

SEM examination of the $>53 \mu \mathrm{m}$ fraction reacted with 0.1 $\mathrm{M}$ base showed clear evidence of secondary precipitation on quartz, feldspar, and biotite particles, and $\mathrm{NaOH}$ attack on mica (particularly biotite) (Fig. 6). Over the 168-day exposure to 0.1 $\mathrm{M} \mathrm{NaOH}$ at $50^{\circ} \mathrm{C}$, quartz particles exhibited little evidence of dissolution (Fig. 6a, b, c). With time, however, secondary precipitates accumulated on all mineral surfaces. EDS analysis of secondary precipitates on quartz surfaces had a Na-Al-Si-O composition with morphology illustrated by Figure $6 \mathrm{~d}$. Biotite samples isolated from pristine sediment exhibited surfaces clear of precipitates, with sharp, clean edges (Fig. 6e). After 168 days in $0.1 \mathrm{M} \mathrm{NaOH}$, the biotite surfaces were crenulated, the edges were dulled, and curled, and secondary precipitates were clearly present (Fig. 6f).

SEM inspection of the $>53 \mu \mathrm{m}$ sediment fraction exposed to $1 \mathrm{M}$ and $3 \mathrm{M} \mathrm{NaOH}$ showed the same basic trends observed for the $0.1 \mathrm{M} \mathrm{NaOH}$ treatment (Fig. 7). The accumulation of
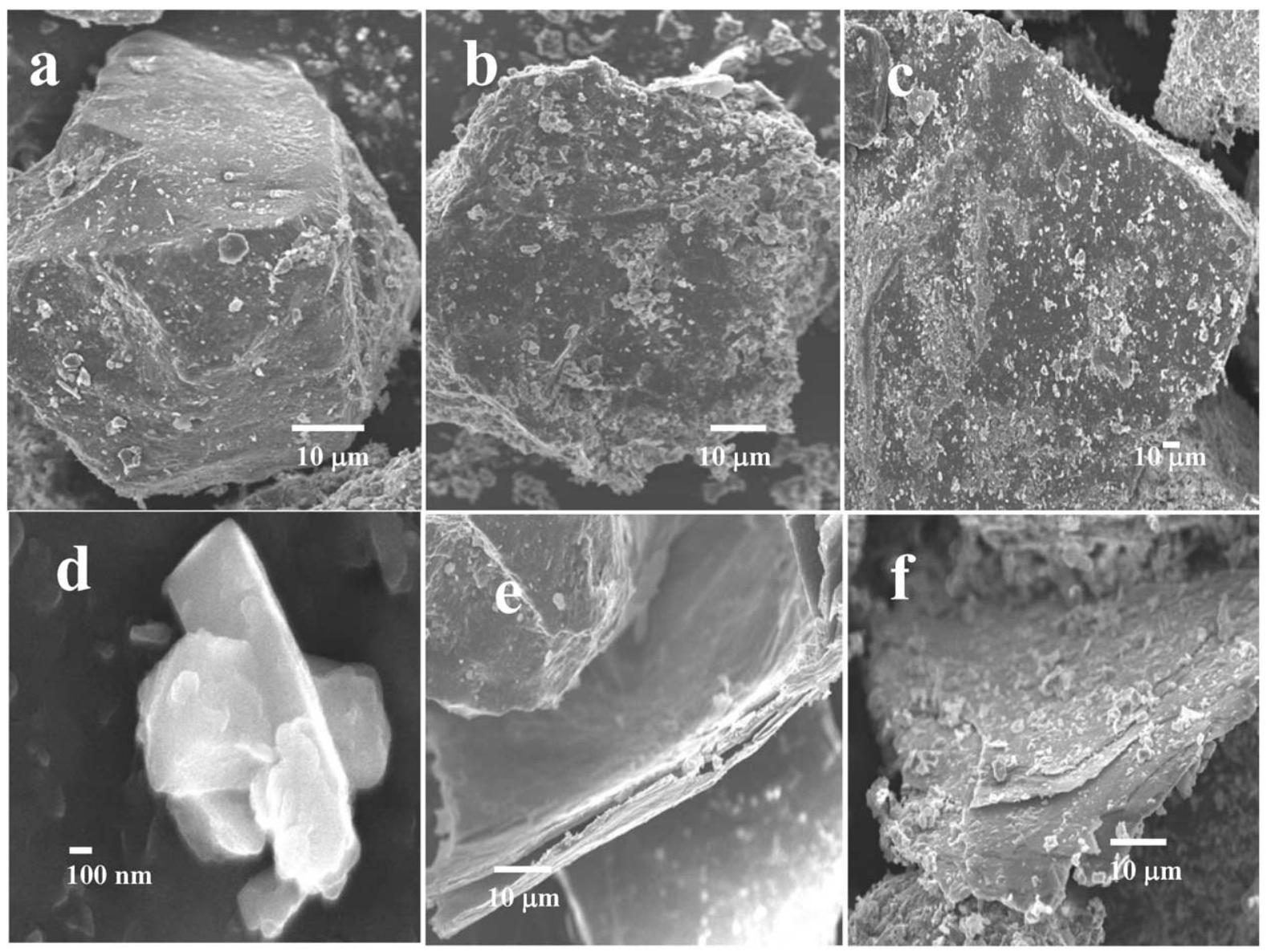

Fig. 6. Electron micrographs of mineral phases from the Hanford sediment ( $>53 \mu \mathrm{m}$ fraction) after exposure to $0.1 \mathrm{M}$ $\mathrm{NaOH}$ in $1 \mathrm{M} \mathrm{NaNO}_{3}$ at $50^{\circ} \mathrm{C}$ for selected time periods: a) quartz particle, $\mathrm{t}=56 \mathrm{~d}$; b) quartz particle, $\mathrm{t}=112 \mathrm{~d}$; c) quartz particle, $\mathrm{t}=168 \mathrm{~d} ; \mathrm{d}$ ) suspected secondary tetranatrolite on quartz particle $\mathrm{t}=168 \mathrm{~d} ; \mathrm{e}$ ) pristine biotite; f) biotite $\mathrm{t}=168 \mathrm{~d}$. 


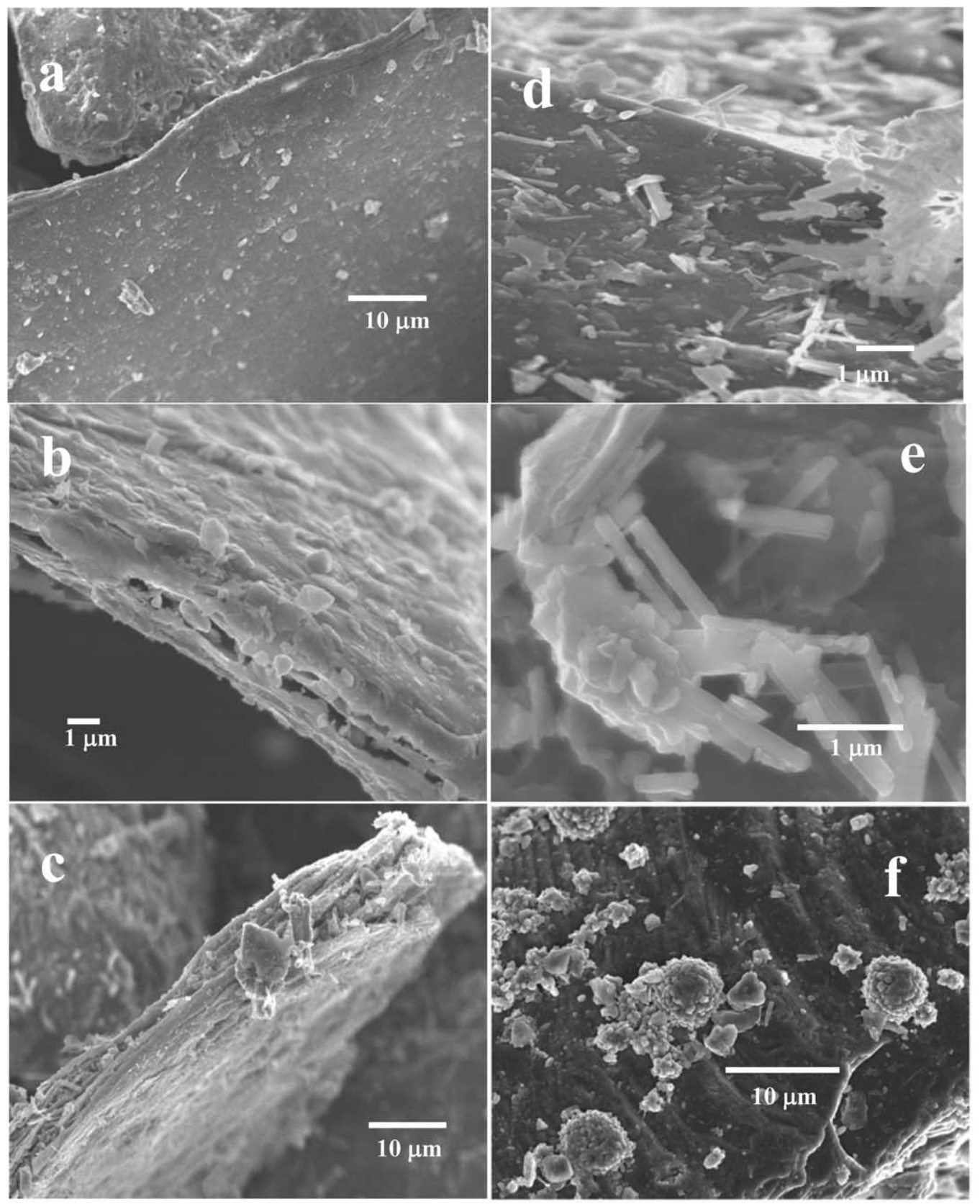

Fig. 7. Electron micrographs of mineral phases from the Hanford sediment ( $>53 \mu \mathrm{m}$ fraction) after exposure to $1 \mathrm{M}$, or $3 \mathrm{M} \mathrm{NaOH}$ in $1 \mathrm{M} \mathrm{NaNO}_{3}$ at $50^{\circ} \mathrm{C}$ for selected time periods: a) biotite, $1 \mathrm{M} \mathrm{NaOH}, \mathrm{t}=7 \mathrm{~d}$; b) biotite, $1 \mathrm{M} \mathrm{NaOH}, \mathrm{t}=24 \mathrm{~d}$; c) biotite, $3 \mathrm{M} \mathrm{NaOH}, \mathrm{t}=33 \mathrm{~d}$; d) quartz grain with surface precipitate of $\mathrm{Na}_{2} \mathrm{Al}_{2} \mathrm{Si}_{3} \mathrm{O}_{10} \cdot 2 \mathrm{H}_{2} \mathrm{O}, 1 \mathrm{M} \mathrm{NaOH}, \mathrm{t}=33 \mathrm{~d}$; e) higher magnification of d; f) feldspar with secondary precipitate of $\mathrm{Na}_{2} \mathrm{Al}_{2} \mathrm{Si}_{3} \mathrm{O}_{10} \cdot 2 \mathrm{H}_{2} \mathrm{O}, 3 \mathrm{M} \mathrm{NaOH}, t=7$. The precipitates in e, and $\mathrm{f}$ show clearly different morphologies, but exhibit identical $\mathrm{Si} / \mathrm{Al}$ ratios and composition (as determined by EDS).

secondary precipitates on quartz, feldspar, and mica (particularly biotite) increased with base contact time, and as the $\mathrm{NaOH}$ concentration was increased. The biotite particles showed similar edge and surface deterioration after just 7 to 24 days of contact time with $3 \mathrm{M}$ and $1 \mathrm{M} \mathrm{NaOH}$ as compared to 168 days at $0.1 \mathrm{M} \mathrm{NaOH}$ (compare Fig. 6e, f with Fig. 7a-c). As with the $0.1 \mathrm{M} \mathrm{NaOH}$ treated sediments, secondary precipitates in the 1 and $3 \mathrm{M} \mathrm{NaOH}$ treatments tended to accumulate on all mineral surfaces. The secondary precipitates observed at $1 \mathrm{M} \mathrm{NaOH}$ appeared as rod-like structures that with time, clustered together (Fig. 7d, e). With $3 \mathrm{M} \mathrm{NaOH}$, the secondary precipitates exhibited hemisphere morphology (Fig. 7f). The precipitated $\mathrm{Na}_{14} \mathrm{Al}_{12} \mathrm{Si}_{13} \mathrm{O}_{51} \cdot 6 \mathrm{H}_{2} \mathrm{O}$ appears zeolite-like in both structures and the composition.

The precipitation of zeolite and zeolite-like minerals from highly basic mineral suspensions was not unexpected (see section 1.0). The absence of cancrinite formation was also not surprising with the absence of aluminate in the initial contact 
Table 1. Cation exchange capacities of Hanford sediment as a function of time and temperature of exposure to $0.1 \mathrm{M} \mathrm{OH}$.

\begin{tabular}{cccc} 
& & \multicolumn{2}{c}{$\mathrm{CEC}\left(\mathrm{eq} / \mathrm{g} \times 10^{-5}\right)^{\mathrm{a}}$} \\
\cline { 3 - 4 } Saturating ion & $\begin{array}{c}\text { Base exposure } \\
(\mathrm{d})\end{array}$ & $10^{\circ} \mathrm{C}$ & $50^{\circ} \mathrm{C}$ \\
\hline \multirow{2}{*}{$\mathrm{Na}$} & 0 & \multicolumn{2}{c}{$4.26 \pm 0.12$} \\
& 56 & $2.25 \pm 0.03$ & $4.71 \pm 0.13$ \\
& 112 & $3.08 \pm 0.16$ & $6.73 \pm 0.11$ \\
& 168 & $3.06 \pm 0.07$ & $7.42 \pm 0.84$ \\
\hline
\end{tabular}

${ }^{a}$ The initial CEC (time $=0$ ) is taken from Zachara et al. (2002) where $\mathrm{n}=6$; the other time period CEC values were determined in this study with $\mathrm{n}=3$.

solution. Qafoku et al. (2003a, b) investigated the dissolution/ precipitation of Hanford sediment in contact with solutions identical to the current study $\left(1 \mathrm{M} \mathrm{NaOH} / 1 \mathrm{M} \mathrm{NaNO}_{3}\right.$; at $\left.50^{\circ} \mathrm{C}\right)$ except with increasing $\mathrm{Al}$ concentrations $(0.055 \mathrm{~mol} / \mathrm{L}$ to 0.22 $\mathrm{mol} / \mathrm{L}$ ). Even the lowest aluminate contact solutions were oversaturated with respect to cancrinite, and exhibited Si/Al molar ratios between 0.096 and 0.284 , which is as much as 10 to 50 times less than the current study's Si/Al ratio (Fig. 1c). While the solution data from the current study were not modeled, a comparison of current $\mathrm{Si} / \mathrm{Al}$ ratios to that of Qafoku et al. (2003a, b), Barnes et al. (1999) and Bickmore et al. (2001) suggests that the present system was always undersaturated with respect to the cancrinite. The precipitation of zeolites or zeolite-like secondary mineral phases from mineral dissolution in the current high $\mathrm{pH}$, saline solutions, or Al-chabazite (Chorover et al., 2003) from kaolinite-high pH, saline solutions aluminate suspensions - arise because of temperature and initial solid phase differences. In the more complex aluminate suspensions aqueous-mediated transformation has been suggested to follow as aluminosilicate species $\rightarrow$ amorphous phase $\rightarrow$ zeolite $\rightarrow$ sodalite $\rightarrow$ cancrinite (Barnes et al., 1999).

\subsection{Changes in Sediment CEC After Exposure to $0.1 \mathrm{M} \mathrm{NaOH}$}

At $10^{\circ} \mathrm{C}$, the sediment exhibited a substantial decrease in CEC within 56 days (47\%), followed by an increase after 168 days to approximately $72 \%$ of its original CEC. At $50^{\circ} \mathrm{C}$ and $0.1 \mathrm{M} \mathrm{NaOH}$, the sediment showed a steady increase in CEC, which by the end of the experiment had increased by $74 \%$ to $7.42 \pm 0.84 \times 10^{-5} \mathrm{eq} / \mathrm{g}$ (Table 1$)$. The increase at $50^{\circ} \mathrm{C}$ was well represented by a linear model $(\mathrm{R}=0.976)$ whose slope equated to a growth in CEC of $2.04 \times 10^{-7} \mathrm{eq} / \mathrm{g} / \mathrm{d}$. The increase in CEC observed at $50^{\circ} \mathrm{C}$ was expected (discussed below), but the trend in CEC at $10^{\circ} \mathrm{C}$ was not. The apparent decrease in $\mathrm{CEC}$ at $10^{\circ} \mathrm{C}$ may have resulted from incomplete $\mathrm{K}^{+}$removal during the post-base treatment washing process which would hinder an accurate determination of CEC. If the $\mathrm{NaNO}_{3}$ washing of base treated sediment did not effectively remove the exchangeable $\mathrm{K}^{+}$, the CEC measurements would probably be understated for both temperatures.

Using the same sediment as the current study and Zachara et al. (2002), Steefel et al. (2003) determined a CEC of 12.19 $\times 10^{-5} \mathrm{eq} / \mathrm{g}$ based on the equivalent sum of cations eluted by a pre-flush of a sediment column using $1 \mathrm{M} \mathrm{NaNO}_{3}$ or $1 \mathrm{M}$ $\mathrm{KNO}_{3}$; similarly, ${ }^{22} \mathrm{Na}$ elution from a sediment column yielded a CEC of $12.0 \times 10^{-5} \mathrm{eq} / \mathrm{g}$. Using the ${ }^{22} \mathrm{Na}$ batch technique similar to that used by Zachara et al. (2002) and the current study, Steefel et al. (2003) found the CEC substantially lower and similar to that of Zachara et al. (2002); $4.6 \times 10^{-5} \mathrm{eq} / \mathrm{g}$. With pristine Hanford sediments, apparent Na-saturated material contained appreciable residual $\mathrm{Ca}^{2+}$ not exchanged by $\mathrm{Na}^{+}$, and resupplied by feldspar dissolution while in suspension. This residual $\mathrm{Ca}^{2+}$ must be considered for accurate CEC determination. In the present study, residual $\mathrm{K}^{+}$could have had a similar effect at both temperatures. However, for the comparative purposes of this study's sediment $\mathrm{Cs}^{+}$exchange with that of Zachara et al. (2002), the use of the same CEC determination technique was required.

The increase in CEC observed in sediment exposed to $1 \mathrm{M}$ $\mathrm{NaOH} / 1 \mathrm{M} \mathrm{NaNO}_{3}$ at $50^{\circ} \mathrm{C}$ probably resulted from interlayer expansion of micas (particularly the more reactive biotite). Interlayer expansion exposed interlayer $\mathrm{K}^{+}$to exchange, and increased the CEC. Potassium release from biotite between $\mathrm{pH}$ 2 to 10 , showed an initial rapid release through ion exchange, followed by diffusion-controlled release of interlayer ions as the mica layers expanded (Malmström and Banwart, 1997). Under base attack Samson et al. (2005) observed essentially no dissolution of biotite basal surfaces, but grain edges were exfoliated and splayed. The dissolution of biotite has been correlated primarily with edge surface area (Turpault and Trotignon, 1994; Trotignon and Turpault, 1992 as reported by Nagy, 1995). In the current study, basal surfaces showed signs of weathering, but it was the mica edges that exhibit significant changes after reaction with base (Fig. 6 and 7).

Concomitant with base attack of micas, the formation of tetranatrolite could also contribute to the observed CEC increase at $50^{\circ} \mathrm{C}$. As stated previously, tetranatrolite is part of the natrolite subgroup of zeolites. These zeolites are characterized as fibrous, small-pore zeolites whose framework is composed of $\mathrm{T}_{5} \mathrm{O}_{10}$ units formed from linking five $\mathrm{TO}_{4}$ tetrahedra ( $\mathrm{T}$ $=\mathrm{Al}, \mathrm{Si}$ ) that are then connected along the c-axis to form natrolite chains (Lee et al., 2002). Charge balancing cations (e.g., $\mathrm{Na}, \mathrm{K}$ etc) reside along the channels created by c-axis linkages. Tetranatrolite and natrolite differ in disorder degree in the tetrahedral sites; the latter exhibiting almost complete disordering (Lee et al., 2000). The small pores associated with natrolite limits cation exchange between $\mathrm{Na}^{+}$and large radius monovalent cations such as $\mathrm{Cs}^{+}$, and divalent cations (e.g., $\mathrm{Sr}^{2+}$ ). In studies with a natural natrolite at $60^{\circ} \mathrm{C}, \mathrm{Ca}, \mathrm{Sr}, \mathrm{Cs}$, $\mathrm{Rb}$, and $\mathrm{Mn}$, exchange for $\mathrm{Na}$ was less than $2 \%$ of the total available exchange sites while $\mathrm{K}$ exchange accounted for $42 \%$ of the available sites (Dyer and Faghihian, 1998). Even with the restricted pore size, tetranatrolite's exchangeable $\mathrm{Na}^{+}$could contribute to CEC measured by ${ }^{22} \mathrm{Na}$ exchange.

\section{4. $\mathrm{Cs}^{+}$Exchange/Selectivity with $0.1 \mathrm{M} \mathrm{NaOH}$ Treated Hanford Sediment at $\mathbf{p H ~} 8$}

Na-saturated Hanford sediment was exposed to $0.1 \mathrm{M}$ $\mathrm{NaOH} / 1 \mathrm{M} \mathrm{NaNO}_{3}$ solution at $10^{\circ} \mathrm{C}$ or $50^{\circ} \mathrm{C}$ for 56,112 or 168 days, washed free of base, $\mathrm{pH}$ adjusted to $\mathrm{pH} 8$, and air-dried. Short-term $(16 \mathrm{~h}) \mathrm{Cs}^{+}$adsorption studies (total $\mathrm{Cs}^{+}$concentrations $10^{-9}$ to $10^{-1} \mathrm{~mol} / \mathrm{L}$ ) with washed sediment in $1 \mathrm{M}$ $\mathrm{NaNO}_{3}$ yielded $\mathrm{Cs}^{+}$adsorption isotherms that were of the Freundlich type with slopes $(1 / \mathrm{n})<1$, suggesting sorption site 
heterogeneity. A comparison of this study's isotherm data with those from Zachara et al. (2002), at the same solid to solution ratio $(50 \mathrm{~g} / \mathrm{L})$ and $1 \mathrm{M} \mathrm{NaNO}_{3}$, showed no substantive differences between the data regardless of sediment pretreatment (data not shown).

In order to isolate possible effects of base exposure on $\mathrm{Cs}^{+}$ adsorption, conditional ion-exchange equilibrium constants $\left(K_{c}\right)$ were computed from the short-term $\mathrm{Cs}^{+}$adsorption isotherm data. Calculated $K_{c}$ 's were based on the $\mathrm{Na}^{+} \rightarrow \mathrm{Cs}^{+}$ exchange reaction

$$
\begin{gathered}
C s_{(a q)}^{+}+N a X=C s X+N a_{(a q)}^{+}, \quad \text { with } \\
K_{c}=\left[N a^{+}\right]\left[E_{C s X}\right] /\left[C s^{+}\right]\left[E_{N a X}\right],
\end{gathered}
$$

where [] denotes concentration. $E_{C s X}$ and $E_{N a X}$ are the surface equivalent fractions for $\mathrm{Cs}^{+}$and $\mathrm{Na}^{+}$calculated as

$$
E_{C s X}=q_{C s} / Q
$$

where $q_{C s}=$ the adsorption density in eq/g, $Q=$ the appropriate time dependent CEC (eq/g), and $E_{N a X}=1-E_{C s X}$.

For sediments pretreated with $0.1 \mathrm{M} \mathrm{NaOH} / 1 \mathrm{M} \mathrm{NaNO}_{3}$ at $10^{\circ} \mathrm{C}$, the $\mathrm{Na}^{+} \rightarrow \mathrm{Cs}^{+}$exchange ${ }_{N a}^{C s} K_{c}$ showed no clear evidence of time dependence over the range of $\mathrm{E}_{\mathrm{Csx}}$ investigated (Fig. 8a). While there was some fluctuation in ${ }_{N a}^{C s} K_{c}$ with time (the 112-d values are slightly lower, and the 168-d values are slightly higher than the 56-d values), there was no consistent trend of changing ${ }_{\mathrm{Na}}^{\mathrm{Cs}} \mathrm{K}_{c}$ with base exposure. The fact that there was no clear base contact-time dependence indicated that the exchanger phase selectivity was not altered over the time period of the study. In contrast, the ${ }_{N a}^{C s} K_{c}$ values for the $50^{\circ} \mathrm{C}$ pretreated sediment showed a small but consistent trend of decreasing selectivity with increasing base contact time (Fig. $8 \mathrm{~b})$. The $\Delta_{N a}^{C s} K_{c}$ for $\mathrm{Cs}^{+}$sorption densities below $\log \mathrm{E}_{\mathrm{CsX}}$ $=-2.5$ were approximately 0.2 to $0.4 \log$ units after 168 days. The displacement at the higher $\log \mathrm{E}_{\mathrm{Cs}}$ values $(>-2)$ was more difficult to discern due to data variability. While not significant, there was a perceptible displacement toward lower $\mathrm{Cs}^{+}$adsorption densities with base pretreatment exposure time.

The short-term $\mathrm{Cs}^{+}$adsorption data were modeled using the multi-site ion exchange model (Zachara et al., 2002), and the CEC measured at $\mathrm{t}=112$ days (Table 1 ). These fitted data were compared to a calculated $\log { }_{N a}^{C s} K_{c}$ versus $\log \mathrm{E}_{\mathrm{CsX}}$ curve based on the constants and concentrations for the two exchange sites $\left[\mathrm{K}_{\mathrm{c}}(\mathrm{I})=\right.$ FES sites; $\mathrm{K}_{\mathrm{c}}(\mathrm{II})=$ planar sites $]$ developed for pristine Hanford sediment by Zachara et al. (2002). Modeling results are shown in Table 2, and Figure 8a, b.

For the $10^{\circ} \mathrm{C}$ base pretreated sediments, the two-site ion exchange model described the $\mathrm{Cs}^{+}$sorption data well (Fig. 8a; solid line). The fitted $\log { }_{N a}^{C s} K_{c}$ versus $\log \mathrm{E}_{\mathrm{CsX}}$ curve was essentially identical to that calculated for pristine Hanford sediment except the fitted curve was uniformly displaced upward over the entire range of $\mathrm{E}_{\mathrm{CsX}}$ by about $\log { }_{\mathrm{Na}}^{C s} K_{c}=0.45$ (compare $\left(\mathrm{K}_{\mathrm{c}}\right.$ (I) and $\mathrm{K}_{\mathrm{c}}$ (II) values). The $\log _{N a}^{C s} K_{c}$ displacement, however, disappeared when $\mathrm{E}_{\mathrm{CsX}}$ and ${ }_{\mathrm{Na}}^{\mathrm{Cs}} K_{c}$ values were calculated based on the pristine sediment's CEC (data not shown). This result suggests that there was an underestimation of CEC for the $10^{\circ} \mathrm{C}$ pretreated sediment, probably as a result of incomplete saturation of the sediment prior to the short-term $\mathrm{Cs}^{+}$
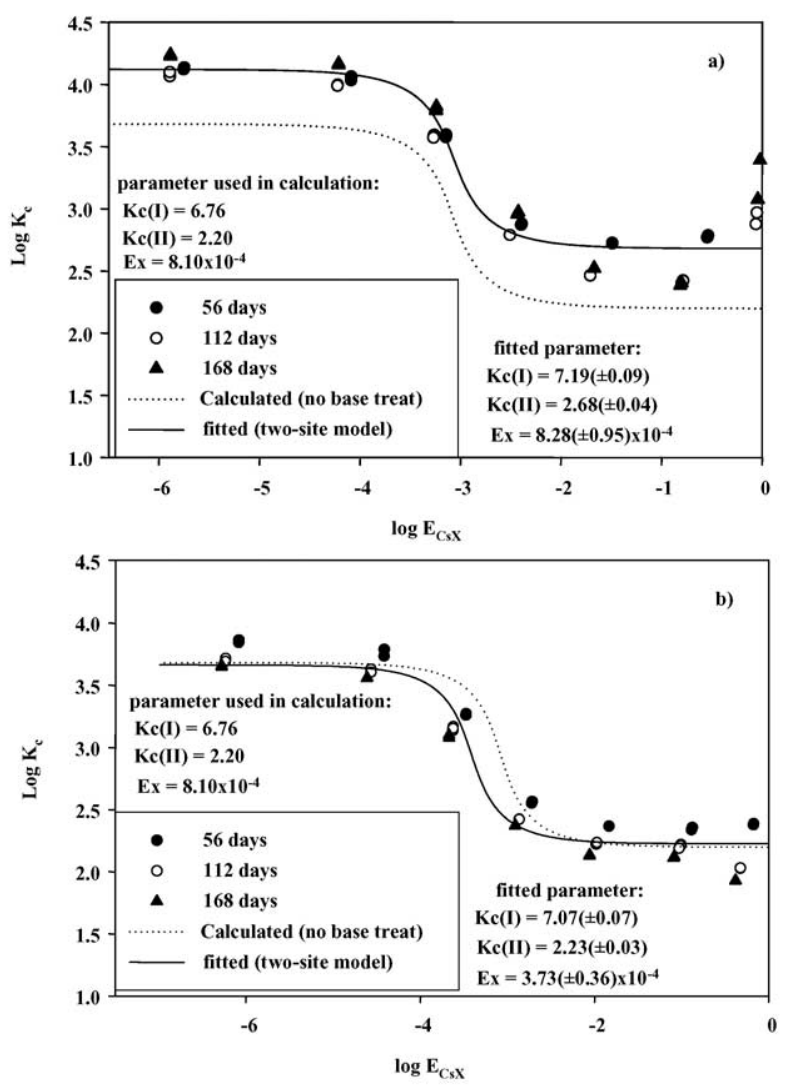

Fig. 8. Conditional equilibrium constants $\left({ }_{N a}^{C S} K_{c}\right)$ for $\mathrm{Cs}^{+}$in $\mathrm{Na}^{+}$ electrolyte at $\mathrm{pH} 8.0$ after pretreatment with $0.1 \mathrm{M}$ base for 56,112 , and 168 days at a) $10^{\circ} \mathrm{C}$, and b) $50^{\circ} \mathrm{C}$; the two-site cation exchange model results for (dashed line) the $\mathrm{K}_{\mathrm{c}}$ prediction for Cs sorption to pristine Hanford sediment (from Zachara et al., 2002), and (solid line) the fitted $\mathrm{K}_{\mathrm{c}}$ for the base treated sediment; Ex values are the FES site concentrations listed in Table 2.

sorption study. Also, exposure to $0.1 \mathrm{M} \mathrm{NaOH} / 1 \mathrm{MNaNO}_{3}$ at $10^{\circ} \mathrm{C}$ had little effect on Hanford sediment $\mathrm{Cs}^{+}$selectivity.

The two-site ion exchange model (based on $\mathrm{t}=112 \mathrm{~d}$ CEC) described $\mathrm{Cs}^{+}$sorption to the $50^{\circ} \mathrm{C}$ base pretreated sediment well (Fig. 8b). In comparison to the calculated selectivity for pristine sediment, the base treated sediment's $\mathrm{K}_{\mathrm{c}}(\mathrm{I})$ was slightly higher 6.76 and 7.19 , respectively), but the $K_{c}($ II) values were identical. The effect of base pretreatment was reflected, however, in the modeling by the decreased fraction of high-energy sites (Ex in Fig. 8b), which translated to a decrease from 3.45 $\times 10^{-8} \mathrm{eq} / \mathrm{g}$ in pristine materials to $2.94 \times 10^{-8} \mathrm{eq} / \mathrm{g}$ base pretreated sediment; a $15 \%$ loss of FES sites over a 112 day period.

Short-term $\mathrm{Cs}^{+}$sorption to base pretreated sediment and the model simulations of the sorption data correlated well with the mineralogic examination of reacted sediment. At $10^{\circ} \mathrm{C}$, no significant mineralogic changes were observed, and $\mathrm{Cs}^{+}$sorption and model simulations were essentially identical to that of the pristine sediment. At $50^{\circ} \mathrm{C}$, the post reacted sediment showed limited loss of clay-sized phyllosilicates, base attack to the edges of mica, and the precipitation of tetranatrolite. These base induced mineralogic changes were reflected in the shortterm $\mathrm{Cs}^{+}$sorption and subsequent model results by a slightly 
Table 2. Multiple site modeling parameters for $\mathrm{Cs}^{+}$sorption by pristine Hanford sediment, and sediment after 112 days exposure to $0.1 \mathrm{M} \mathrm{NaOH}$ at $10^{\circ} \mathrm{C}$ and $50^{\circ} \mathrm{C}$.

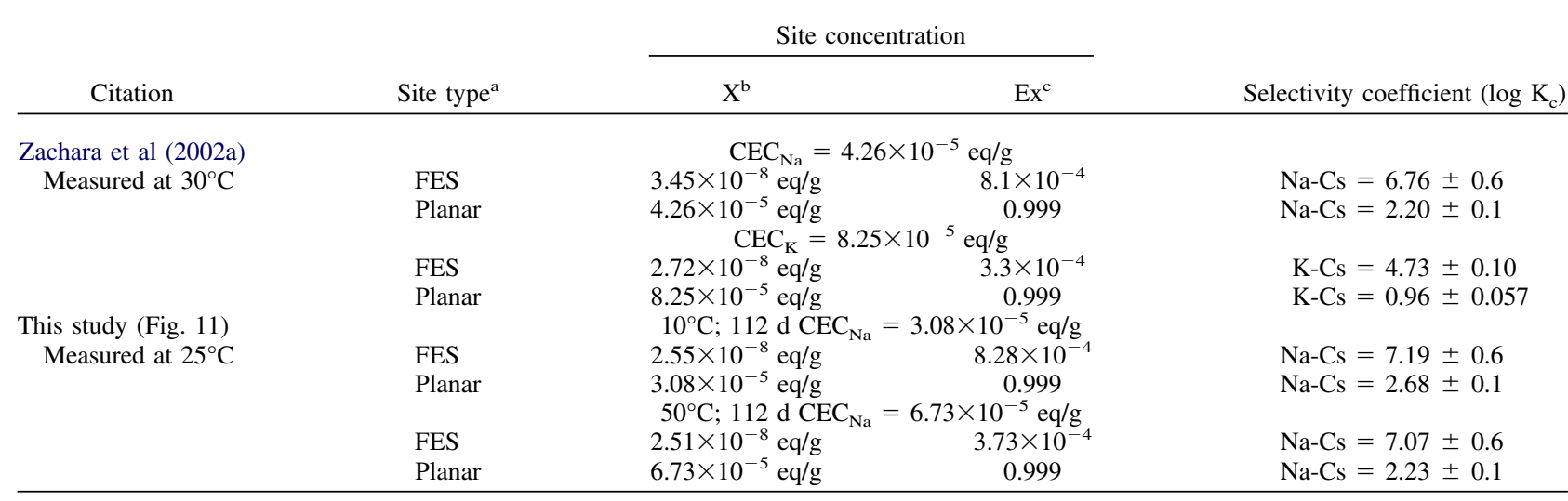

${ }^{\text {a }}$ Site type refers to frayed edge sites (FES) and the basal plane sites (Planar) that represent the cation exchange complex in the multiple site model.

$\mathrm{b}$ Total concentration.

${ }^{\mathrm{c}} \mathrm{E}_{\mathrm{x}}=$ site concentration/ $\mathrm{CEC}_{\mathrm{n}}$; where $\mathrm{n}$ denotes saturating cation or temperature.

higher $\mathrm{K}_{\mathrm{c}}(\mathrm{I})$ value, higher $\mathrm{CEC}$, and a small calculated decrease in FES site population compared to a pristine sediment. At both temperatures, however, $\mathrm{Cs}^{+}$adsorption densities were almost identical to those observed by Zachara et al. (2002) for pristine sediment.

\section{5. $\mathrm{Cs}^{+}$Behavior with Hanford Sediment During Base Attack at 0.1 M NaOH}

In pristine Hanford sediment, $\mathrm{Cs}^{+}$sorption kinetics (at $25^{\circ} \mathrm{C}$ ) varied with electrolyte $(\mathrm{Na})$ concentration and $\left[\mathrm{Cs}^{+}\right]_{\text {total }}$. A steady-state $\mathrm{Cs}^{+}$adsorption density was attained within $12 \mathrm{~h}$ and maintained for $120 \mathrm{~d}$ in $5 \mathrm{~mol} / \mathrm{L} \mathrm{NaNO}_{3}$ and $10^{-4} \mathrm{~mol} / \mathrm{L}$ $\mathrm{CsNO}_{3}$, but at $0.005 \mathrm{~mol} / \mathrm{L} \mathrm{NaNO}_{3} \mathrm{Cs}^{+}$adsorption reached its maximum in $12 \mathrm{~h}$ and then declined by $21 \%$ over $120 \mathrm{~d}$ (Zachara et al., 2002). At $0.1 \mathrm{~mol} / \mathrm{L} \mathrm{NaNO}_{3}$ and $3.2 \times 10^{-7}$ $\mathrm{mol} / \mathrm{L} \mathrm{CsNO}_{3}, 90 \%$ of the eventual steady-state adsorption density was attained within 12 to $24 \mathrm{~h}$, and steady-state conditions were attained in $10 \mathrm{~d}$ (Liu et al., 2003b). In contrast to pristine sediments, $\mathrm{Cs}^{+}$adsorption to Hanford sediment in contact with $0.1 \mathrm{M} \mathrm{NaOH} / 1.0 \mathrm{M} \mathrm{NaNO}_{3}$ increased throughout the 112 -d study regardless of $\left[\mathrm{Cs}^{+}\right]_{\text {total }}$ or temperature $\left(10^{\circ} \mathrm{C}\right.$ or $50^{\circ} \mathrm{C}$ ) (Fig. 9a, b, c). Only at $50^{\circ} \mathrm{C}$ and the highest targeted adsorption density did $\mathrm{Cs}^{+}$adsorption reach a temporary $(\sim 7$ d) stable surface density (Fig 9c). $\mathrm{Cs}^{+}$adsorption at $10^{\circ} \mathrm{C}$ was not followed prior to $14 \mathrm{~d}$.

Adsorption of $\mathrm{Cs}^{+}$was greater at $10^{\circ} \mathrm{C}$ at the low and intermediate surface densities (Fig. 9a, b), which was in line with the negative $\mathrm{Na}-\mathrm{Cs}$ ion exchange enthalpies for highenergy $(-17.87 \pm 2.01 \mathrm{~kJ} / \mathrm{mol})$ and low-energy $(-4.82 \pm 0.44$ $\mathrm{kJ} / \mathrm{mol}$ ) sites associated with pristine Hanford sediment (Liu et al., 2003a). These negative enthalpies translated into a $\Delta \log$ $\mathrm{Kc}(\mathrm{I})$ and $\mathrm{K}(\mathrm{II})$ of -0.20 and -0.74 for $\mathrm{Cs}^{+}$exchange as the temperature increased from $30^{\circ} \mathrm{C}$ to $65^{\circ} \mathrm{C}$ (Liu et al., 2003a). At the highest surface density (Fig. 9c) $\mathrm{Cs}^{+}$sorption was contrary to the results of Liu et al. (2003a) (discussed below).

As a comparison, $\mathrm{Cs}^{+}$sorption to the Hanford sediment during base attack (depicted in Fig. 9) was simulated using the two-site ion exchange model of Zachara et al. (2002). Model simulations were based on $\mathrm{CEC}, \mathrm{K}_{\mathrm{c}}(\mathrm{I})$ and $\mathrm{K}_{\mathrm{c}}(\mathrm{II})$, and site populations determined from short-term $\mathrm{Cs}^{+}$exchange studies conducted after the sediment was reacted with base for $112 \mathrm{~d}$ (Section 3.5; Table 2). The high- and low-energy site $\mathrm{K}_{\mathrm{c}}$ values were corrected for temperature based on the enthalpy values from Liu et al. (2003a) (Table 3). The results of these calculations are depicted in Figure 9 by a dashed line $\left(10^{\circ} \mathrm{C}\right)$, or a solid line $\left(50^{\circ} \mathrm{C}\right)$.

The slow increase in $\mathrm{Cs}^{+}$sorption observed at $10^{\circ} \mathrm{C}$ from $14 \mathrm{~d}$ to $112 \mathrm{~d}$ is reminiscent of a slow steady increase in exchange sites; however, this is difficult to reconcile with the CEC measurements (section 3.4), and the minimal effect base attack had on ${ }_{\mathrm{Na}}^{\mathrm{Cs}} K_{c}$ (section 3.5). Yet, the model simulations match the 112- $\mathrm{d} \mathrm{Cs}^{+}$ sorption data well at all three surface densities (Fig. 9). Given these results, coupled with no detectable changes in mineralogy (section 3.3), and the lack of variation in ${ }_{N a}^{C s} K_{c}$ after exposure to 0.1 $\mathrm{M} \mathrm{NaOH}$ for up to 168 days it appears that sediment dissolution at $10^{\circ} \mathrm{C}$ and $0.1 \mathrm{M} \mathrm{NaOH}$ had no observable effect on $\mathrm{Cs}^{+}$ sorption to Hanford sediment.

The $50^{\circ} \mathrm{C}, 112-\mathrm{d} \mathrm{Cs}^{+}$adsorption densities were consistently under-predicted by the model simulations (Fig. 9a, b, c). While the lower targeted $\mathrm{Cs}^{+}$adsorption densities were only slightly under-predicted $(16 \%)$, the highest $\mathrm{Cs}^{+}$surface density was under-predicted by 57\%. A $0.65 \log$ unit increase in the $\mathrm{Kc}(\mathrm{I})$ was required to match the highest $\mathrm{Cs}^{+}$sorption experimental data. These results suggested that $\mathrm{Cs}^{+}$sorption to the Hanford sediment during base attack $\left(0.1 \mathrm{M} \mathrm{NaOH} / 1 \mathrm{M} \mathrm{NaNO}_{3}\right)$ at $50^{\circ} \mathrm{C}$ altered the site selectivity, or generated sorption sites that were not captured in the short-term $\mathrm{Cs}^{+}$sorption studies [from which the $\mathrm{Kc}$ (I and II) were generated; section 3.5, Fig. 8], and were not altered/formed at $10^{\circ} \mathrm{C}$.

$\mathrm{Cs}^{+}$sorption $\left(50^{\circ} \mathrm{C}\right)$ at the highest $\mathrm{Cs}^{+}$adsorption density was static for 7 days, and then increased through the rest of the study (Fig. 9c); the increased sorption correlated to the onset of tetranatrolite precipitation. These data suggested that increased $\mathrm{Cs}^{+}$sorption at $50^{\circ} \mathrm{C}$ was related to tetranatrolite precipitation, probably via ion exchange or inclusion within the precipitate. While the small pores associated with natrolite-type zeolites limit cation exchange between $\mathrm{Na}^{+}$and large radius monovalent 


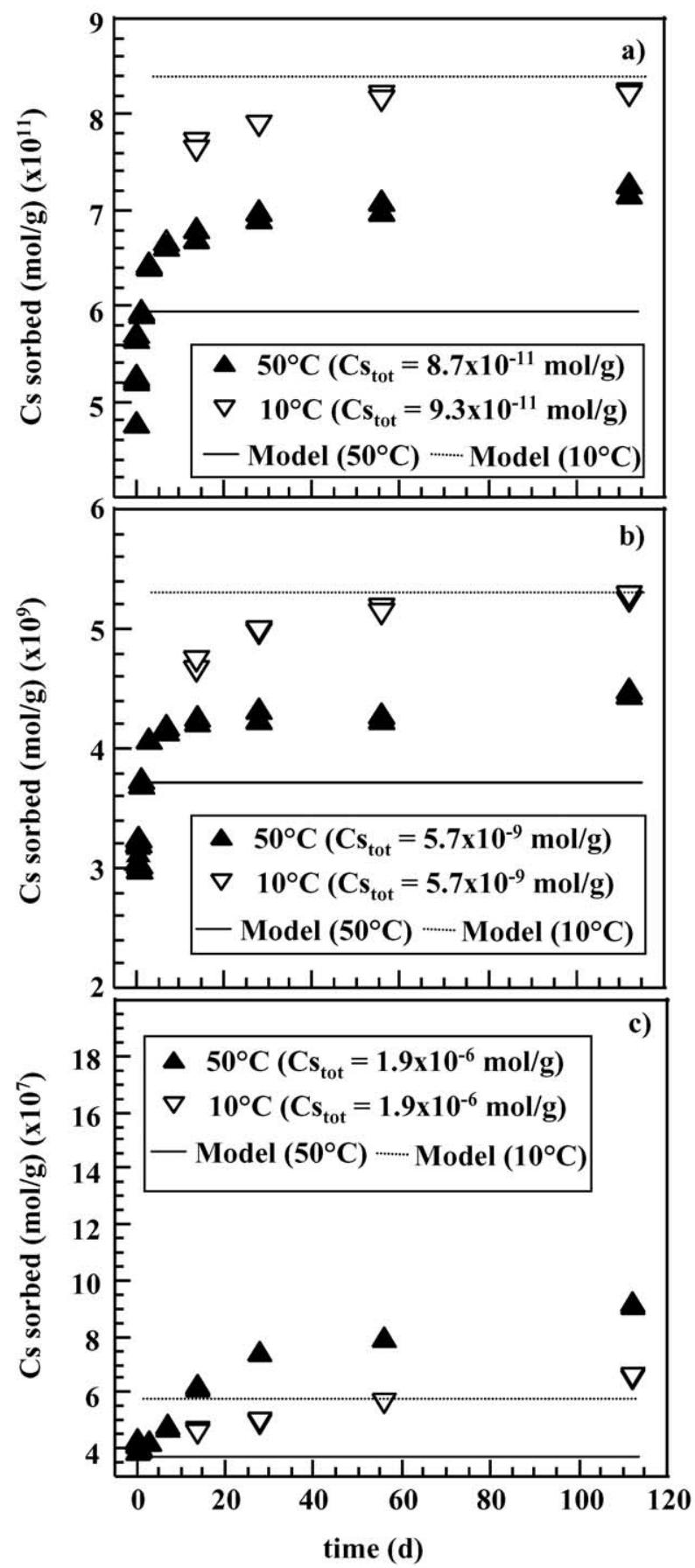

Fig. 9. $\mathrm{Cs}^{+}$sorption with time on the Hanford sediment at $10^{\circ} \mathrm{C}$ or $50^{\circ} \mathrm{C}$ from $0.1 \mathrm{M} \mathrm{NaOH}$ in $1 \mathrm{M} \mathrm{NaNO}_{3}$ at three different initial aqueous $\mathrm{CsNO}_{3}$ concentrations a) $2.1 \times 10^{-9} \mathrm{M}$, b) $1.3 \times 10^{-7} \mathrm{M}$, and c) $4.5 \times 10^{-5} \mathrm{M}$; the horizontal lines are model simulations for Cs sorption at 112-d based on $\mathrm{K}_{\mathrm{c}}$ values corrected for enthalpy effects $\left(10^{\circ} \mathrm{C}\right.$ dashed line; $50^{\circ} \mathrm{C}$ solid line).

cations $(\mathrm{Cs}, \mathrm{Rb})$ and divalent cations $(\mathrm{Ca}, \mathrm{Sr})$, Dyer and Faghihian (1998) measured a small $(<2 \%)$ but significant $\mathrm{Na}^{+} \rightarrow \mathrm{Cs}^{+}$ exchange component for natrolite over a two week period that suggested a slow exchange process. If the tetranatrolite observed in this study exhibited similar exchange kinetics it
Table 3. Multiple site model parameters for $\mathrm{Na}-\mathrm{Cs}$ exchange on the Hanford sediment with $K_{c}$ values corrected for the influence of temperature $^{\mathrm{a}}$.

\begin{tabular}{cccccc}
\hline & \multicolumn{2}{c}{ Selectivity coefficient } & & \multicolumn{2}{c}{ Site concentration (eq/g) } \\
\cline { 2 - 3 } \cline { 5 - 6 } $\begin{array}{c}\text { Temperature } \\
\left({ }^{\circ} \mathrm{C}\right)\end{array}$ & $\log \mathrm{K}_{\mathrm{c}}(\mathrm{I})$ & $\log \mathrm{K}_{\mathrm{c}}(\mathrm{II})$ & & FES $^{\mathrm{b}}$ & Planar $^{\mathrm{b}}$ \\
\hline $10^{\mathrm{c}}$ & 7.57 & 2.78 & & $2.55 \times 10^{-8}$ & $3.08 \times 10^{-5}$ \\
$50^{\mathrm{c}}$ & 6.51 & 2.08 & & $2.51 \times 10^{-8}$ & $6.73 \times 10^{-5}$ \\
$10^{\mathrm{c}}$ & 7.26 & 2.33 & & $3.45 \times 10^{-8}$ & $4.26 \times 10^{-5}$ \\
$50^{\mathrm{c}}$ & 6.32 & 2.16 & & $3.45 \times 10^{-8}$ & $4.26 \times 10^{-5}$ \\
\hline
\end{tabular}

${ }^{\mathrm{d}}$ Values for $\log \mathrm{K}_{\mathrm{c}}$ (I) and (II) are from Zachara et al. (2002a) measured at $30^{\circ} \mathrm{C}$ (Table 2).

${ }^{\text {a }}$ Correction estimates based on Liu et al. (2003).

${ }^{\mathrm{b}}$ frayed edge sites (FES) and the basal plane sites (Planar) represent the cation exchange complex in the multiple site model.

${ }^{c}$ Values for $\log \mathrm{K}_{\mathrm{c}}$ (I) and (II) are based on selectivity coefficients measured at $25^{\circ} \mathrm{C}$ (Table 2).

would not have been interrogated during the short-term exchange studies.

Assuming that at $50^{\circ} \mathrm{C}$ the $\mathrm{Si}$ dissolution rate was equal to tetranatrolite precipitation rate and reasonably constant (at about $\left.3.27 \times 10^{-5} \mathrm{~mol} / \mathrm{L} / \mathrm{h} / \mathrm{g}\right)$, a maximum of $7.5 \times 10^{-4}$ moles $(0.28 \mathrm{~g})$ of tetranatrolite would have been precipitated over 105 days. At a minimum, about $0.03 \mathrm{~g}$ of tetranatrolite precipitated, based on the estimate that about $1 \%$ by weight was required to detect a neoform by the XRD technique used. The exchangeable $\mathrm{Na}^{+}$associated with this range in tetranatrolite mass would be $1.5 \times 10^{-3}$ moles to $1.6 \times 10^{-4}$ moles. During the $105-\mathrm{d}$ period at $50^{\circ} \mathrm{C}$, the sediment sorbed, at the highest density, $3.47 \times 10^{-7}$ moles of $\mathrm{Cs}^{+}$, which would displace about $0.23 \%$ of tetranatrolite exchangeable $\mathrm{Na}$ assuming the minimum mass precipitated.

We surmise that $\mathrm{Cs}^{+}$sorption during base attack by $0.1 \mathrm{M}$ $\mathrm{NaOH}$ at $50^{\circ} \mathrm{C}$, was dominated by ion exchange with the phyllosilicates particularly at the lower $\mathrm{Cs}^{+}$adsorption densities, and $\mathrm{Cs}^{+}$ion exchange was not greatly affected. At higher $\mathrm{Cs}^{+}$adsorption densities, planar phyllosilicates sites initially dominated $\mathrm{Cs}^{+}$exchange, but tetranatrolite $\mathrm{Na} \rightarrow \mathrm{Cs}$ exchange accounted for the time dependent sorption of $\mathrm{Cs}^{+}$, and the ion exchange model's under prediction of the $112-\mathrm{d} \mathrm{Cs}^{+}$surface density.

\section{6. $\mathrm{Cs}^{+}$Sorption During Base Attack by $1 \mathrm{M}$ or $3 \mathrm{M}$ $\mathrm{NaOH}$ and $1.0 \mathrm{M} \mathrm{NaNO}_{3}$ at $50^{\circ} \mathrm{C}$.}

$\mathrm{Cs}^{+}$sorption increased over time with exposure to $1 \mathrm{M}$ $\mathrm{NaOH}$ in a similar manner to $0.1 \mathrm{M} \mathrm{NaOH}$ (Fig. 10a, b, c). At the lower adsorption densities (Fig. 10a, b) $\mathrm{Cs}^{+}$sorption increased sharply during the initial $7 \mathrm{~d}$, and over the following $105 \mathrm{~d}$ increased by about the same percentage as that observed at $0.1 \mathrm{M} \mathrm{NaOH}(3-5 \%)$. Unlike the $0.1 \mathrm{M} \mathrm{NaOH}$ system, however, the lag, or static, period at the highest adsorption density in $0.1 \mathrm{M} \mathrm{NaOH}$ (Fig. 9c) was not evident at $1 \mathrm{M} \mathrm{NaOH}$ (Fig. 10c). At the lowest $\mathrm{Cs}^{+}$adsorption density (Fig. 10a) time dependent $\mathrm{Cs}^{+}$sorption was constant or slightly decreased between $14 \mathrm{~d}$ and $56 \mathrm{~d}$, and then increased from $56 \mathrm{~d}$ to $112 \mathrm{~d}$.

The slightly convex nature of $\mathrm{Cs}^{+}$sorption time profile in $1 \mathrm{M}$ $\mathrm{NaOH}$ (Fig. 10a) was more pronounced at $3 \mathrm{M} \mathrm{NaOH}$, and was observed at all $\mathrm{Cs}^{+}$adsorption densities (Fig. 10a, b, c). All three $\mathrm{Cs}^{+}$concentrations showed an immediate increase in $\mathrm{Cs}^{+}$adsorp- 

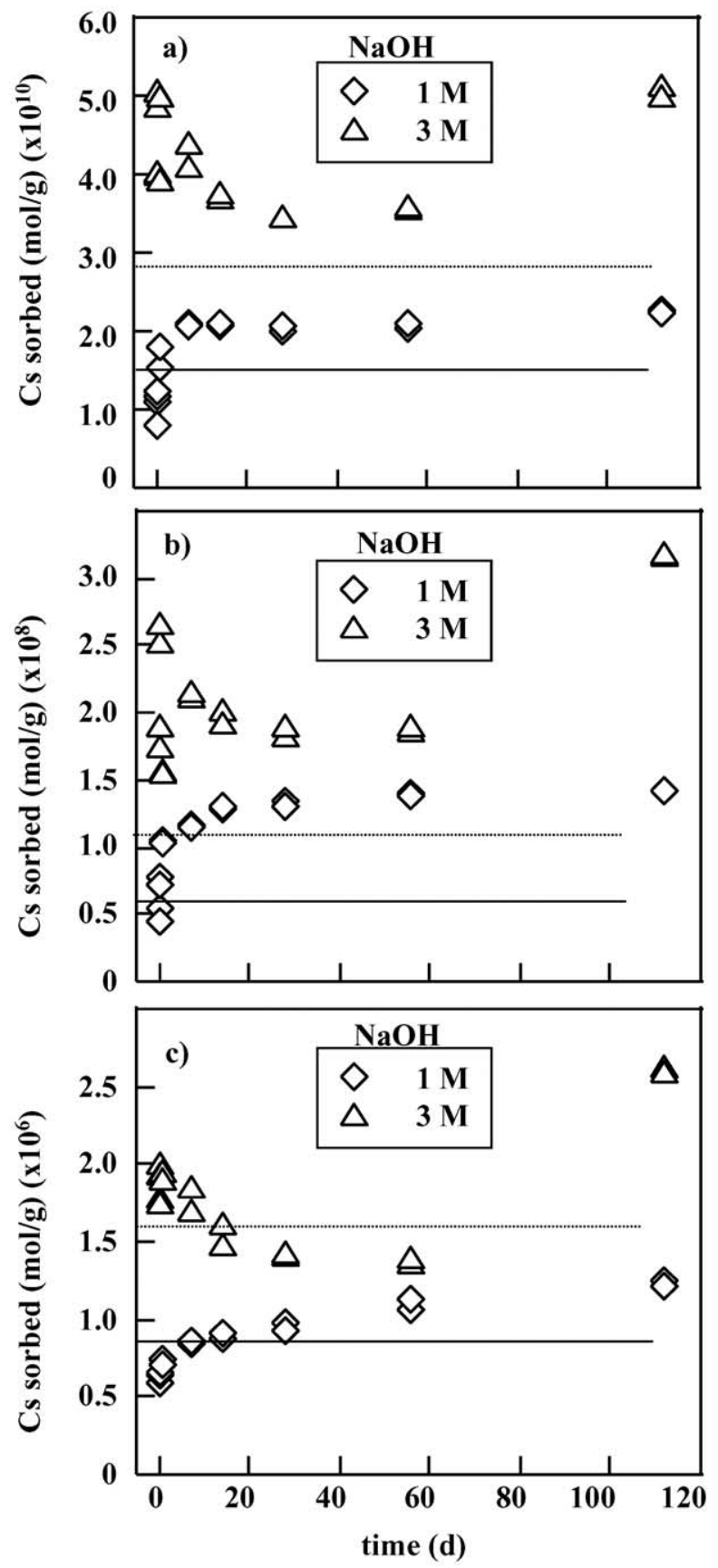

Fig. 10. $\mathrm{Cs}^{+}$sorption with time on the Hanford sediment at $50^{\circ} \mathrm{C}$ from $1 \mathrm{M}$, or $3 \mathrm{M} \mathrm{NaOH}$ in $1 \mathrm{M} \mathrm{NaNO}_{3}$ at different initial aqueous $\mathrm{CsNO}_{3}$ concentrations a) $6.1 \times 10^{-9} \mathrm{M}$, or $1.3 \times 10^{-8} \mathrm{M}$ at $1 \mathrm{M} \mathrm{NaNO}_{3}$, or $3 \mathrm{M} \mathrm{NaOH}$, respectively, b) $4.0 \times 10^{-7} \mathrm{M}$, or $8.8 \times 10^{-7} \mathrm{M}$ at $1 \mathrm{M}$ $\mathrm{NaNO}_{3}$, or $3 \mathrm{M} \mathrm{NaOH}$, respectively, and c) $1.3 \times 10^{-4} \mathrm{M}$, or $3.0 \times 10^{-4}$ $\mathrm{M}$ at $1 \mathrm{M} \mathrm{NaNO}_{3}$, or $3 \mathrm{M} \mathrm{NaOH}$, respectively; solid lines represent $\mathrm{Cs}^{+}$ sorption to pristine sediment at $30^{\circ} \mathrm{C}$ in $1 \mathrm{M} \mathrm{NaNO}_{3}$ at initial $[\mathrm{Cs}]_{\mathrm{aq}}$ used in $1 \mathrm{M}$ base experiments, and the dashed lines represent $\mathrm{Cs}^{+}$ sorption to pristine sediment at $30^{\circ} \mathrm{C}$ in $1 \mathrm{M} \mathrm{NaNO}_{3}$ at initial $[\mathrm{Cs}]_{\mathrm{aq}}$ used in $3 \mathrm{M}$ base experiments.

tion when contacted with base that began to decrease after $24 \mathrm{~h}$. This decrease continued for approximately 40 days; the percentage decrease correlated with adsorption density: $10^{-10} \mathrm{~mol} / \mathrm{g}(23 \%)$ $>10^{-8} \mathrm{~mol} / \mathrm{g}(17 \%)>10^{-6} \mathrm{~mol} / \mathrm{g}(10 \%)$.
For comparative purposes, model simulations were performed for $\mathrm{Cs}^{+}$adsorption to the pristine Hanford sediment at $30^{\circ} \mathrm{C}$, with the initial $\left[\mathrm{Cs}^{+}\right]_{\mathrm{aq}}$ used for each $\mathrm{NaOH}$ concentration and $1 \mathrm{M}$ $\mathrm{NaNO}_{3}$; the results are plotted in Figure 10a, b, c as solid (1 M $\mathrm{NaOH})$ and dashed lines (3 $\mathrm{M} \mathrm{NaOH})$. Because of enthalpy considerations, greater competition for exchange sites from $\left[\mathrm{Na}^{+}\right]_{\mathrm{aq}}\left([\mathrm{Na}]_{\text {total }}=2 \mathrm{M}\right.$ and $4 \mathrm{M}$ for 1 and $3 \mathrm{M}$ base treatments, respectively), and clay-sized fraction dissolution (section 3.3), $\mathrm{Cs}^{+}$sorption should have been greater on the pristine sediment for an equivalent sorption time. At $1 \mathrm{M} \mathrm{NaOH}, \mathrm{Cs}^{+}$sorption rapidly increased beyond that estimated for pristine sediment (Fig. 10a, b, c); likewise, at $3 \mathrm{M} \mathrm{NaOH}$ only at the highest $\mathrm{Cs}^{+}$adsorption density was this condition temporally approximated (Fig. 10c). If, as hypothesized, secondary mineral precipitation (section 3.1, Fig. 3b) did not occur during the initial $24 \mathrm{~h}$, excess $\mathrm{Cs}^{+}$adsorption beyond that expected for the pristine sediment was probably the result of base attack on the mica fraction of the sediment via both layer (delamination) and edge weathering (Fanning et al., 1989 and references therein).

Beyond $24 \mathrm{~h}$, base attack resulted in substantial dissolution of the clay fraction phyllosilicates (Fig. 5), and precipitation of $\mathrm{Na}_{14} \mathrm{Al}_{12} \mathrm{Si}_{13} \mathrm{O}_{51} \cdot 6 \mathrm{H}_{2} \mathrm{O}$. While the effect of $1 \mathrm{M}$ base on the population and selectivity of high-energy exchange sites is not known, the time-variant sorption behavior of $\mathrm{Cs}^{+}$(Fig. 10a, b, c) suggested that the CEC, and primarily the concentration of low affinity exchange sites on silt and sand-sized mica particles, did increase over time. The increase in $\mathrm{Cs}^{+}$adsorption observed at the highest adsorption density was probably the result of mica delamination, which in conjunction with precipitation of the $\mathrm{Na}_{14} \mathrm{Al}_{12} \mathrm{Si}_{13} \mathrm{O}_{51} \cdot 6 \mathrm{H}_{2} \mathrm{O}$ could generate a greater $\mathrm{Cs}^{+}$adsorption potential.

While the decrease in adsorption densities observed between 3 and 40 days in $3 \mathrm{M} \mathrm{NaOH}$ may be attributed to the dissolution of the clay fraction phyllosilicates (Fig. 6), the reasons for the increase beyond 40 days was not clear. The formation of $\mathrm{Na}_{14} \mathrm{Al}_{12} \mathrm{Si}_{13} \mathrm{O}_{51} \cdot 6 \mathrm{H}_{2} \mathrm{O}$, and its apparent mass increase coincident with dissolution of the sediments clay-sized phyllosilicates suggested that $\mathrm{Na}_{14} \mathrm{Al}_{12} \mathrm{Si}_{13} \mathrm{O}_{51} \cdot 6 \mathrm{H}_{2} \mathrm{O}$ was responsible for the late stage increase in adsorption density. Ultimately, however, we could not determine if the neoform influenced $\mathrm{Cs}^{+}$adsorption, and if it did, whether uptake occurred through an exchange process or a precipitation/ripening process.

In a similar study, exposure of kaolinite to simulated $\mathrm{Cs}^{+}$ containing HLW resulted in the precipitation of a zeolite (Alchabalite), nitrate-sodalite, and $\mathrm{NO}_{3}$-cancrinite (Chorover et al., 2003). Accumulation of Cs with the precipitates was coupled to crystal growth and ripening of the neoforms, and the amount of desorbable (exchangeable) $\mathrm{Cs}^{+}$by an unbuffered $\mathrm{Mg}\left(\mathrm{NO}_{3}\right)_{2}$, while always low, decreased with reaction time (Chorover et al., 2003). Similarly, reaction between simulated HLW and Hanford sediment produced analcime (a zeolite) after 7 days at $200^{\circ} \mathrm{C}$ and a $1: 1$ soil to solution ratio, while at $90^{\circ} \mathrm{C}$ and $1: 10$ soil to solution ratio cancrinite formed the predominant reaction product (Nyman et al., 2000). While both of these secondary minerals incorporated $\mathrm{Cs}^{+}$, the analcime sequestered as much as 4 times that of canrinite.

Because all size fractions of the Hanford sediment contain mica, an alternative explanation is that larger mica grain weathering could qualitatively account for the $\mathrm{Cs}^{+}$behavior. At the higher base concentrations, the data suggest that the clay-sized fraction 
may have only a minor effect on $\mathrm{Cs}^{+}$adsorption. At present, however, there is no way to separate these competing hypotheses. What is clear from the batch reactor studies is that, even at high $\mathrm{NaOH}$ concentrations, base-induced dissolution of the Hanford sediment did not adversely influence the sorption of $\mathrm{Cs}^{+}$. Rather, by 112 days, $\mathrm{Cs}^{+}$sorption increased at all initial $\mathrm{Cs}^{+}$concentrations compared to sorption on pristine sediments.

\subsection{Implications of Base Dissolution for $\mathrm{HLW} \mathrm{Cs}^{+}$ Migration in the Subsurface}

A slant borehole was drilled in 2001, beneath the SX-108 tank at Hanford that leaked $380 \mathrm{~kL}$ of caustic, saline self-boiling REDOX HLW in 1969 (Serne and Burke, 1997; Jones et al., 2000; Zachara et al., 2002, 2001; Serne et al., 2002a). The REDOX

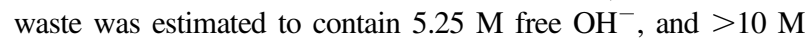
$\mathrm{NaNO}_{3}$ at a temperature of $100^{\circ} \mathrm{C}(+)$. The first sediment core sample that was affected by the HLW plume was about $4.3 \mathrm{~m}$ below the tank bottom. Examination of the cored material with depth delineated three important observations: i) the high concentration of $\mathrm{Na}^{+}$in the HLW displaced exchangeable cations $\left(\mathrm{Ca}^{2+}\right.$, $\mathrm{Mg}^{2+}, \mathrm{K}^{+}$) ahead of the body of the waste plume; ii) evidence of base attack, and secondary precipitation on sediment mineral phases were observed to about $10 \mathrm{~m}$ below the tank bottom; and iii) base attack intensity was greatest near the tank (McKinley et al., 2001; Zachara et al., 2001; Serne et al., 2002a).

SEM micrographs of borehole sediment revealed that micas just below the tank bottom $(4.3 \mathrm{~m})$ were pervasively altered (edges dulled, and curled, crenulated surfaces) with copious secondary precipitates (McKinley et al., 2001). Secondary precipitates on quartz and feldspar grains from the core exhibited a cruciate morphology and $\mathrm{Na}-\mathrm{Al}-\mathrm{Si}-\mathrm{O}$ composition similar to those found in the current studies at higher base concentrations (McKinley et al., 2001). With depth, mica alteration and evidence of secondary precipitates diminished, and below $10 \mathrm{~m}$ there was no evidence of base attack; mica flakes were sharp-edged with little surface or edge precipitates. Clearly, the alteration/precipitation depth profile reflects base neutralization by mineral dissolution and precipitation reactions and probably recarbonization.

McKinley et al. (2001), found evidence of secondary smectites in the cored materials most altered by base attack. Secondary smectite formation either through a transformation mechanism (via biotite) or as a precipitation reaction could occur under the chemical, and temperature conditions induced by the leaked HLW fluids (Borchardt, 1989 and references therein). Unlike the present study, which observed only $\mathrm{Na}_{14} \mathrm{Al}_{12} \mathrm{Si}_{13} \mathrm{O}_{51} \cdot 6 \mathrm{H}_{2} \mathrm{O}$ as the primary precipitate after $112-\mathrm{d}$ of reaction with $1 \mathrm{M}$ and $3 \mathrm{M} \mathrm{NaOH}$, the cored sediments have been in ground for almost 40 years at temperatures of $70^{\circ} \mathrm{C}$ to $100^{\circ} \mathrm{C}$, and the $\mathrm{pH}$ has been reduced to more natural levels $(9.5$ to 7.9). The formation of Na-Al-Si-O composition solids observed in the current study and remnants of similar materials observed under the SX-108 tank may indicate that the secondary precipitates observed here are the first stages in a reaction sequence. Autoradiography analysis of individual radioactive particles from the SX-108 borehole found ${ }^{137}$ Cs activity associated with minute secondary precipitates with chemical composition (Na-Al-Si-O) and morphology consistent with neoforms found in the current study (McKinley et al., 2001).

As in earlier studies with the Hanford sediment (Zachara et al.,
2002; Liu et al., 2003a, b), $\mathrm{Cs}^{+}$adsorption in the present study is seen as a cation exchange process whose selectivity varies with $\mathrm{Cs}^{+}$adsorption density. Unlike earlier work with this sediment, however, a series of reactions occur with base contact that is concomitant/sequential with the $\mathrm{Cs}^{+}$exchange reaction. The basedriven reactions alter the $\mathrm{Cs}^{+}$exchange complex, but, surprisingly, do not adversely impact $\mathrm{Cs}^{+}$sorption. Despite the dissolution of clay-sized phyllosilicates at high base concentrations, $\mathrm{Cs}^{+}$ adsorption is greater than that predicted for pristine sediment. A number of factors (e.g., rock:water ratio, temperature, solution composition, etc.) influence the precipitation of secondary phase precipitation (amount, mineralogy) after sediment exposure to high base solutions. The neoforms observed to date (zeolites, feldpathoids) exhibit small potential to sorb $\mathrm{Cs}^{+}$. This small sorption potential, coupled with the fairly unique mica distribution and quantity across all size-fractions in the Hanford sediment, appears to mitigate the impact of base dissolution on $\mathrm{Cs}^{+}$sorption.

The similarities between laboratory reacted sediment, and those retrieved from the vasdose zone in Hanford's high level waste tank farms suggests that base reactions will not significantly effect the retardation of $\mathrm{Cs}^{+}$in these sediments. The results reported here and those of Zachara et al. (2002) and Liu et al. (2003a, b), indicate that high $\mathrm{Na}$ concentrations and elevated temperature, not base attack, are the major factors causing any expedited $\mathrm{Cs}^{+}$ migration beneath leaked HLW tanks.

Acknowledgments - Research was supported by the Environmental Management Sciences Program (EMSP) and the Hanford Remediation and Closure Science Project. Pacific Northwest National Laboratory is operated for the DOE by Battelle Memorial Institute under Contract DE-AC06-76RLO 1830.

Associate editor: K. L. Nagy

\section{REFERENCES}

Amrhein C., Haghnia G. H., Kim T. S., Mosher P. A., Gagajena R. C., Amaanios T., and De La Torre L. (1996) Synthesis and properties of zeolites from coal fly ash. Environ. Sci. Technol. 30, 735-742.

Babcock K. L. and Schultz R. K. (1970) Isotopic and conventional determination of exchangeable sodium percentage of soil in relation to plant growth. Soil Sci. 109, 19-22.

Barnes M. C., Addai-Mensah J., and Gerson A. R. (1999) The mechanism of the sodalite-to-cancrinite phase transformation in the synthetic spent Bayer liquor. Micropor. Mesopor. Mater. 31, 287 302.

Bauer A. and Berger G. (1998) Kaolinite and smectite dissolution rate in high molar $\mathrm{KOH}$ solutions at $35^{\circ}$ and $80^{\circ} \mathrm{C}$. Appl. Geochem. 13, 905-916.

Bauer A., Velde B., and Berger G. (1998) Kaolinite transformation in high molar KOH solutions. Appl. Geochem. 13, 619-629.

Bickmore B. R., Nagy K. L., Young J. S., and Drexler J. W. (2001) Nitrate-cancrinite precipitation on quartz sand in simulated Hanford tanks solutions. Environ. Sci. Technol. 35, 4481-4486.

Borchardt G. (1989) Smectites. In Minerals In Soil Environments (eds. J. B. Dixon and S. B. Weed), pp. 675-718. Soil Science Society of America, Madison, WI.

Chermak J. A. (1992) Low temperature experimental investigation of the effect of high $\mathrm{pH} \mathrm{NaOH}$ solutions on the Opalinus Shale, Switzerland. Clays Clay Mineral. 40, 650-658.

Chermak J. A. (1993) Low temperature experimental investigation of the effect of high $\mathrm{pH} \mathrm{KOH}$ solutions on the Opalinus Shale, Switzerland. Clays Clay Mineral. 41, 365-372.

Chitra S., Sasidhar P., Lal K. B., and Ahmed J. (1999) The effect of common alkali and alkaline earth metal cations to the sorption of strontium and cesium onto soil. J. Indust. Pollut. Cont. 15, 65-72. 
Chorover J., Choi S., Amistadi M. K., Crosson G., and Mueller K. T. (2003) Linking cesium and strontium uptake to kaolinite weathering in simulated tank waste leachate. Environ. Sci. Technol. 37, 2200-2208.

Cremers A., Elsen A., De Preter P., and Maes A. (1988) Quantitative analysis of radiocesium retention in soils. Nature 335, 247-249.

Dyer A. and Faghihian H. (1998) Diffusion in heteroionic zeolites: part 1. Diffusion of water in heteroionic natrolites. Micropor. Mesopor. Mater. 21, 27-38.

Evans D. W., Alberts J. J., and Clark R. A. III (1983) Reversible ion-exchange fixation of cesium-137 leading to mobilization from reservoir sediments. Geochim. Cosmochim. Acta 47, 1041-1049.

Fanning D. S., Keramidas V. Z., and El-Desoky M. A. (1989) Micas. In Minerals In Soil Environments (eds. J. B. Dixon and S. B. Weed), pp. 551-624. Soil Science Society of America, Madison, WI.

Francis C. W. and Brinkley F. S. (1976) Preferential adsorption of ${ }^{137} \mathrm{Cs}$ to micaceous minerals in contaminated freshwater sediment. Nature 260, 511-513.

Grütter A., von Gunten H. R., Kohler M., and Rössler E. (1990) Sorption, Desorption and Exchange of Cesium on Glaciofluvial Deposits. Radiochim. Acta 50, 177-184.

Hawkins D. B. (1981) Kinetics of glass dissolution and zeolite formation under hydrothermal conditions. Clays Clay Mineral. 29, 331-340.

Jackson M. L. (1969) Soil Chemical Analysis-Advanced Course. pp.127. Prentice-Hall, Inc., Englewood Cliffs, NJ.

Jones T. E., Watrous R. A., and Maclean G. T. (2000) Inventory estimates for single-shell tank leaks in S and SX tank farms. RPP-6285 Rev. O, CH2MHILL Hanford Group, Inc., Richland, Washington.

Kalinowski B. E. and Schweda P. (1996) Kinetics of muscovite, phlogopite, and biotite dissolution and alteration at $\mathrm{pH} 1-4$, room temperature. Geochim. Cosmochim. Acta 60, 367-385.

Kaviratna H. and Pinnavaia T. J. (1995) Acid hydrolysis of octahedral $\mathrm{Mg}^{2+}$ sites in 2:1 layered silicates: An assessment of edge attack and gallery access mechanisms. Clays Clay Mineral. 42, 717-723.

Lee Y., Vogt T., Hriljac J. A., Parise J. B., and Artioli, G. (2002) Pressure induced volume expansion of zeolites in the natrolite family. J. Am. Chem. Soc. 124, 5466-5475.

Lee Y., Kim S. J., and Parise J. B. (2000) Synthesis and crystal structures of gallium- and germanium-variants of the fibrous zeolites with NAT, EDI, and THO structure types. Micropor. Mesopor. Mater. 34, 255-271.

Lin C-F. and Hsi H-C. (1995) Resource recovery of waste fly ash: Synthesis of zeolite-like materials. Environ. Sci. Technol. 29, 1109-1117.

Liu C, Zachara J. M., Qafoku O., and Smith S. C. (2003a) Effect of temperature on $\mathrm{Cs}^{+}$sorption and desorption in subsurface sediments at the Hanford Site, USA. Environ. Sci. Technol. 37, 26402645.

Liu C., Zachara J. M., Smith S. C., McKinley J. P., and Ainsworth C. C. (2003b) Desorption kinetics of radiocesium from subsurface sediments at Hanford site, USA. Geochim. Cosmochim. Acta 67, 28932912.

Ma W., Brown P. W., and Komarneni S. (1998) Characterization and cation exchange properties of zeolite synthesized from fly ashes. $J$. Mater. Res. 13, 3-7.

Maes A. and Cremers A. (1986) Highly selective ion exchange in clay minerals and zeolites. In Geochemical Processes at Mineral Surfaces pp. 254-295. ACS Symposium Series 323, American Chemical Society, Washington, D.C.

Malmström M. and Banwart S. (1997) Biotite dissolution at $25^{\circ} \mathrm{C}$ : The $\mathrm{pH}$ dependence of dissolution rate and stoichiometry. Geochim. Cosmochim. Acta 61, 2779-2799.

McKinley J. P., Zachara J. M., Gassman P. L., Ainsworth C. C., Arey B., McKinley S., Schaef H. T., Smith S. C., Kimberling J., Bish D. L., Chipera S. J., and Snow P. (2001) S-SX Site Mineralogy. In Appendix D: Digest of S\&T Program Evaluations, RPP-7884 (ed. A. J. Knepp) pp. D10-D35. CH2M HILL, Group Inc., Richland.

Ming D. W. and Mumpton F. A. (1989) Zeolites in soils. In Minerals In Soil Environments (eds. J. B. Dixon and S. B. Weed), pp. 675-718. Soil Science Society of America, Madison, WI.

Nagy K. L. (1995) Dissolution and precipitation kinetics of sheet silicates. In Chemical Weathering Rates of Silicate Minerals, Re- views in Mineralogy, Vol. 31, pp. 173-225. Mineralogical Society of America, Washington, D.C.

Nyman M., Krumhansl J. K., Zhang P., Anderson H., and Nenoff T. M. (2000) Chemical evolution of leaked high-level liquid wastes in Hanford soils. In Scientific Basis for Nuclear Waste Management XXIII (eds. R. W. Smith and D. W. Shoesmith) Vol. 608, pp. 225-230. Materials Research Society Symposium Proceedings.

Qafoku N. P., Ainsworth C. C., Szecsody J. E., and Qafoku O. S. (2003a) Aluminum effect on dissolution and precipitation under hyperalkaline conditions: I. Liqiud phase transformations. J. Environ. Qual. 32, 2354-2363.

Qafoku N. P., Ainsworth C. C., Szecsody J. E., Bish D. L., Young J. S., McCready D. E., and Qafoku O. S. (2003b) Aluminum effect on dissolution and precipitation under hyperalkaline conditions: I. Solid phase transformations. J. Environ. Qual. 32, 2364-2372.

Rai R., Felmy A. R., Juracich S. P., and Rao L. (1995) Estimating the hydrogen ion concentration in concentrated $\mathrm{NaCl}$ and $\mathrm{Na}_{2} \mathrm{SO}_{4}$ electrolytes. SAND94-1949, Sandia National Laboratory, Albuquerque, NM.

Samson S. D., Nagy K. L., and Cotton W. B. III. (2005) Transient and quasi-steady-state dissolution of biotite at $22-25^{\circ} \mathrm{C}$ in high $\mathrm{pH}$, sodium, nitrate, and aluminate solutions. Geochim. Cosmochim. Acta 69, 399-413.

Serne R. J., Schaef H. T., Last G. V., Lanigan D. C., Lindenmeier C. W., Clayton R. E., LeGore V. L., O’Hara M. J., Brown C. F., Orr R. D., Kutnyakov I. V., Wilson T. C., Burke D. B., Williams B. A., and Bjornstad B. N. (2002a) Geologic and geochemical data collected from vadose zone sediments from the slant borehole under SX-108 in the S/SX waste management area and preliminary interpretations, PNNL-2001-4, Pacific Northwest National Laboratory, Richland, Washington.

Serne R. J., Bjornstad B. N., Schaef H. T., Williams B. A., Lanigan D. C., Horton D. G., Clayton R. E., Mitroshkov A. V., Legore V. L., O’Hara M. J., Brown C. F., Parker K. E., Kutnyakov I. V., Serne J. N., Last G. V., Smith S. C., Lindenmeier C. W., Zachara J. M., and Burke D. (2002b) Characterization of vadose zone sediment: uncontaminated RCRA borehole core samples and composite samples. PNNL-13757-1, Pacific Northwest National Laboratory, Richland, WA.

Serne R. J. and Burke D. S. (1997). Chemical information on tank supernatants, Cs adsorption from tank liquids onto Hanford sediments, and field observations of Cs migration from past tank leaks. PNNL-11495, Pacific Northwest National Laboratory, Richland, WA.

Steefel C. I., Carrol S., Zhao P., and Roberts S. (2003) Cesium migration in Hanford sediment: a multisite cation exchange model based on laboratory transport experiments. J. Contam. Hydrol. 67, $219-246$.

Trotignon L. and Turpault M-P. (1992) The dissolution kinetics of biotite in dilute $\mathrm{HNO}_{3}$ at $24^{\circ} \mathrm{C}$. In Proc. 7 th International Symposium on Water-Rock Interactions-WRI-7 (eds. Y. K. Kharaka and A. S. Maest), pp. 847-850. Balkema, Rotterdam.

Turpault M-P. and Trotignon L. (1994) The dissolution of biotite single crystals in dilute $\mathrm{HNO}_{3}$ at $24 \mathrm{C}$ : Evidence of an anisotropic corrosion process of micas in acidic solutions. Geochim. Cosmochim. Acta 58, 2761-2775.

Wauters J., Vidal M., Elsen A., and Cremers A. (1996a) Prediction of solid/liquid distribution coefficients of radiocaesium in soils and sediments. Part two: A new procedure for solid phase speciation of radiocaesium. Appl. Geochem. 11, 595-599.

Wauters J., Elsen A., and Cremers A. (1996b) Prediction of solid/liquid distribution coefficients of radioCaesium in soils and sediments. Part three: A quantitative test of a $\mathrm{K}_{\mathrm{D}}$ predictive equation. Appl. Geochem. 11, 601-603.

Zachara J. M., Smith S. C., Liu C., McKinley J. P., Serne R. J., and Gassman P. L. (2002) Sorption of Cs + to micaceous subsurface sediments from the Hanford site, USA. Geochim. Cosmochim. Acta 66, 193-211.

Zachara J. M., Liu C., Smith S. C., and Ainsworth C. C. (2001) Adsorption of Cs in WMA S-SX sediments in the presence of high salt and high base. In Appendix D: Digest of S\&T Program Evaluations, RPP-7884 (ed. A. J. Knepp) CH2M HILL, Group Inc., Richland, WA. 